1

2

3

4

5

6

7

8

9

10

11

12

13

14 15

16 3

Effect of substrate depth, vegetation type, and season on green roof thermal properties

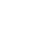

Mert Eksi ${ }^{\mathrm{a}}$, D. Bradley Rowe ${ }^{\mathrm{b}^{*}}$, Indrek S. Wichman $^{\mathrm{c}}$, Jeff A. Andresen $^{\mathrm{d}}$

$4 \quad{ }^{a}$ Michigan State University, Department of Horticulture, East Lansing, MI 48824, USA;

5 Permanent Address: Istanbul University, Faculty of Forestry, Landscape Architecture Department,

Istanbul, Turkey, merteksi@istanbul.edu.tr

${ }^{\mathrm{b}}$ Michigan State University, Department of Horticulture, A212 Plant and Soil Sciences, East Lansing,

MI 48824, USA, rowed@msu.edu

${ }^{\mathrm{c}}$ Michigan State University, Department of Mechanical Engineering, East Lansing, MI 48824, USA, wichman@egr.msu.edu

${ }^{d}$ Michigan State University, Department of Geography Environment Spatial Sciences, East Lansing, MI 48824, USA, andresen@msu.edu

$4 \quad{ }^{*}$ Corresponding author. 


\section{Effect of substrate depth, vegetation type, and season on green roof thermal properties} (1) (1)

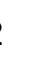
3 (1) (1)

\section{Abstract}

It is generally accepted that green roofs can influence thermal properties of a building, but there is some disagreement on the role that substrate depth and plant species plays in this equation. A study was conducted over a second floor roof in East Lansing, MI, comparing prevegetated mats of a mixture of sedum (depth $=5 \mathrm{~cm})$ to a deeper roof $($ depth $=20 \mathrm{~cm})$ planted with a mixture of 17 herbaceous perennials and grasses. Both roof sections were instrumented with heat flux sensors, thermocouples, moisture sensors, and infrared sensors, and ambient weather conditions were also continuously recorded by a weather station located on the roof. Data were collected for the period of almost a year to cover all four seasons. Also, the roofs were well established and had reached near $100 \%$ plant coverage by the time data collection commenced two years after planting. Most of the differences in temperatures and heat flux through the roof occurred during the summer or winter. During summer, the shallow sedum roof experienced more extreme fluctuations in diurnal substrate temperatures which tended to be warmer during the day, but cooler at night. Heat penetrating into the building on the sedum portion of the roof was consistently greater than the herbaceous section during the afternoon. However, during the night and early morning, heat gain into the building was greater on the herbaceous roof, especially on cloudy and rainy days. During winter, heat transfer through the sedum portion of the roof was affected more by outside environmental conditions, whereas the herbaceous portion of the roof was stable. Although, the sedum roof exhibited more extremes, when daily heat flux values were totaled for each month and each season, the herbaceous roof actually 
experienced more heat entering the building during the summer, but less heat escaping the building during the winter. This is an advantage during the winter months as the herbaceous roof would reduce heating costs. However, contrary to conventional logic that plants with high transpiration rates are superior, during the summer months the sedum roof outperformed the herbaceous roof.

Key words: Building energy, building insulation, heat flux, plant species, thermal performance

\section{Introduction}

Numerous studies have shown that green roofs can lower roof surface, substrate, and waterproofing membrane temperatures, as well as moderate heat flux into and out of a building [1-2]. Thus, they can reduce energy costs for heating and cooling, especially for buildings that are poorly insulated. Getter et.al. [3] found that a shallow extensive green roof reduced heat flow through the building by an average of $13 \%$ in winter and $167 \%$ during summer. Meanwhile, summer temperature values below the growing substrate were $20^{\circ} \mathrm{C}$ cooler than the traditional roof located adjacent to the green portion. Attenuating temperature fluctuations of roof membranes help prolong their lifespan due to less expansion and contraction [4]. In addition, green roofs offer additional economic and ecological services such as mitigation of the urban heat island, management of stormwater, carbon sequestration, reduction of noise and air pollution, providing space for urban food production, providing habitat for wildlife, and improving human health [5-8].

Green roofs can influence the thermal properties of a roof in three ways: the substrate acts as an additional insulation layer; the plant canopy shades the roof surface; and evapotranspiration [2, 910]. The magnitude of this influence also depends on day to day weather conditions such as solar radiation, ambient air temperature, precipitation and thus substrate moisture, and snow cover. Controllable factors include depth and composition of the growing substrate, plant selection, and whether the roof is irrigated.

Some studies have shown that increasing substrate depth results in reductions in heat flux into or out of the building [11-13]. Solar radiation can heat the entire substrate volume much faster when the depth is shallower [14]. In contrast, Lundholm et al. [15] reported that doubling the substrate depth 
from $7.5 \mathrm{~cm}$ to $15 \mathrm{~cm}$ had no impact in lowering net heat loss [15]. Part of the disagreement could be due to substrate composition and compaction. For example, Sailor and Hagos [16] reported that substrates consisting of heat-expanded slate exhibited a thermal conductivity that was two to three times that of substrates that incorporated a silica-based aggregate. Similarly, Pianella et al. [17] found differences among substrates that they tested. Besides the actual materials, their density and particle size distribution will also influence thermal conductivity. As density increases, thermal conductivity and heat flux will also increase [1]. Air pockets in the substrate will increase its ability to act as an insulator [2]. As substrates become compacted when they age, thermal conductivity is likely to increase and thus the substrate's ability to act as an insulator will decrease. Thermal conductivities of moist green roof substrates that have been in place for multiple seasons have exhibited thermal conductivities 30 $40 \%$ higher than their original values due to compaction [16].

In theory, plant species with greater biomass and higher transpiration rates should provide a greater cooling effect. This has been shown to be true in some cases [18-24]. However, in other situations this has been shown not to be true [25-26]. Of course, plant species are highly dependent on substrate depth as deeper substrates allow for plants having greater biomass to survive due to greater substrate moisture. Leaf area index (LAI), stomatal resistance, height, coverage, and albedo (reflectiveness) are five characteristics of plants that can contribute to how plants influence thermal performance [2]. Plants primarily influence cooling during summer, but plant type can also influence the depth of snow cover during winter [15, 27].

Although, plant species with higher transpiration rates might be expected to be more efficient at cooling, plant coverage of the surface may be more important. Shade provided by higher LAI will influence the overall albedo of the roof [11] and decrease solar radiation that reaches the substrate surface $[24,28]$. The surface cooling potential of broadleaf plants was confirmed in a study performed in the UK showing a significant reduction of surface temperature up to $12^{\circ} \mathrm{C}$ [29]. Furthermore, Bowler et al. [30] measured the daily gain in heat on roofs containing shrubs, trees, turf, and bare soil and reported values of $0,15.6,29.2$, and $86.6 \mathrm{~kJ} / \mathrm{m} 2$, respectively. All were significantly better than the conventional hard surface roof which gained $366.3 \mathrm{~kJ} / \mathrm{m} 2$ during the day. A mix of sedum with relatively low biomass was more effective in cooling the roof than meadow vegetation [26]. Likewise, Franzaring et al. [25] reported that monocultures of Phedimus floriferus and Lotus corniculatus provided better cooling than the larger erect species Dianthus carthusianorum and the grass Koeleria 
glauca. A viable explanation may be that the low growing spreading species shaded a greater percentage of the roof than the upright species.

Because there is conflicting information in the literature, the objective of this study is to determine how substrate depth and vegetation type (Sedum compared to herbaceous perennials and grasses) influence the thermal properties of an extensive green roof. Measurements recorded on this site such as heat flux, substrate moisture, temperature distributions will demonstrate the influence of different plant cover and substrates.

\section{Methodology}

\subsection{Climate}

The study was conducted on a $232 \mathrm{~m}^{2}$ green roof located on the Molecular Plant Sciences

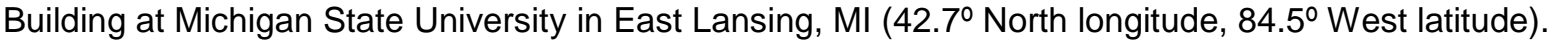
East Lansing has a temperate climate with well-defined seasons that are moderated by the Great Lakes. Winters are cold with an average overnight temperature during January of $-10.1{ }^{\circ} \mathrm{C}$ and have an average annual snowfall of $119 \mathrm{~cm}$. Summer can be hot and humid with an average high temperature during July of $27.8 \stackrel{\circ}{\circ}$. East Lansing is located within USDA (United States Department of Agriculture) Hardiness Zone 5b. Average annual precipitation equals $80.8 \mathrm{~cm}$ and is distributed relatively evenly throughout the growing season. Historically, seasonal rainfall for winter, spring, summer, and autumn equals $12.7,21.5,24.2$, and $22.4 \mathrm{~cm}$, respectively [31]. There are normally 175 sunny days per year. Cloudy days are more common in Michigan than in most parts of North America, in part due to the evaporation of water from the Great Lakes.

\subsection{Roof construction}

The $232 \mathrm{~m}^{2}$ green roof covers the second floor and is surrounded by open areas to the north, west, and south. An adjacent five story building to the east shades parts of the roof until noon as the shadow moves across the roof. The green roof consists of a shallow Sedum area surrounding a deeper section planted with herbaceous perennials and grasses (Fig. 1). Both sections were installed on the same roof slab and are composed of identical layers with the exception of vegetation, substrate 

shown in Table 1.
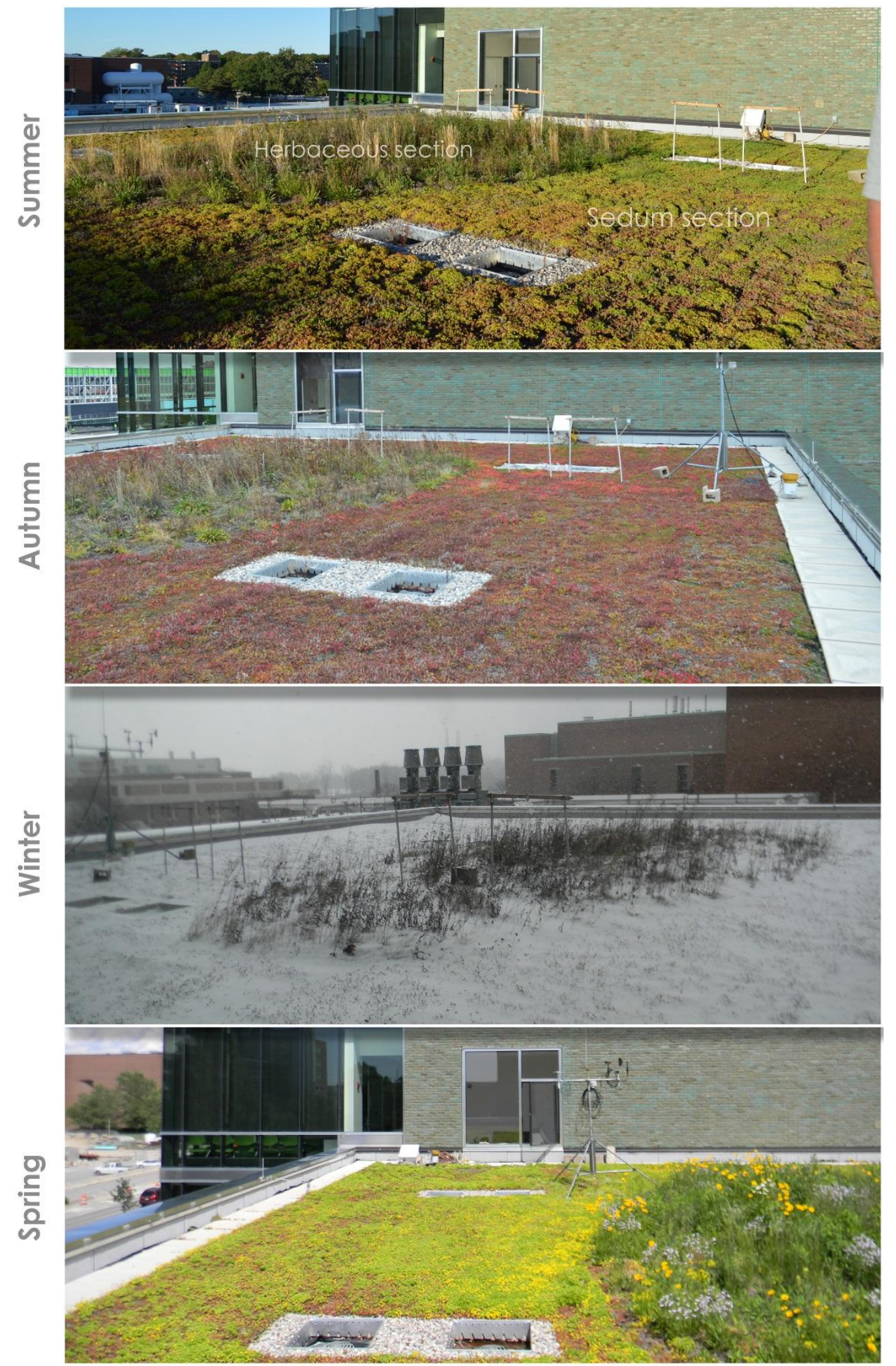

Fig. 1. Green roof during summer, autumn, winter, and spring seasons. 
Table 1 - Description of roofing layers for the herbaceous perennial and sedum roof sections.

\begin{tabular}{|c|c|c|}
\hline $\begin{array}{c}\text { Roofing } \\
\text { layer }\end{array}$ & Herbaceous section & Sedum section \\
\hline Vegetation & $\begin{array}{l}\text { Herbaceous perennials and grasses (67 } \\
\mathrm{m}^{2} \text { ) planted from plugs directly into } \\
\text { substrate (Wildtype Nursery, Mason, MI) }\end{array}$ & $\begin{array}{l}\text { XeroFlor XF301 sedum mats }\left(165 \mathrm{~m}^{2}\right) \\
\text { (XeroFlor America, LLC, Durham, NC) }\end{array}$ \\
\hline Substrate & $\begin{array}{c}\text { XeroFlor XeroTerr }{ }^{\circledR} \text { proprietary growing } \\
\text { medium }(20 \mathrm{~cm} \text { deep) }\end{array}$ & $\begin{array}{c}\text { XeroFlor XeroTerr® proprietary growing } \\
\text { medium (5 cm deep) contained on a XF301 } \\
\text { vegetation carrier }\end{array}$ \\
\hline $\begin{array}{l}\text { Vegetation } \\
\text { carrier }\end{array}$ & Not needed & $\begin{array}{l}\text { XF301 vegetation carrier consisted of an } \\
\text { inverted layer of XF108 (coils facing up) that } \\
\text { held the media and vegetation. An additional } \\
\text { layer of fleece that could hold up to } 6.5 \\
\mathrm{~kg} \cdot \mathrm{m}^{-2} \text { of water was sewn to the bottom }\end{array}$ \\
\hline $\begin{array}{c}\text { Water } \\
\text { retention } \\
\text { fabric }\end{array}$ & \multicolumn{2}{|c|}{$\begin{array}{c}\text { Two layers of XeroFlor XF157 fleece consisting a recycled synthetic fiber mixture of } \\
\text { polyester, polyamide, polypropylene, and acrylic fibers (each } 0.75 \mathrm{~cm} \text { thick with water } \\
\left.\text { retention ability equal to } 10 \mathrm{~kg}^{-2} \mathrm{~m}^{-2}\right)\end{array}$} \\
\hline $\begin{array}{l}\text { Drainage } \\
\text { mat }\end{array}$ & \multicolumn{2}{|c|}{$\begin{array}{c}\text { XeroFlor XF108 drainage mat consisting of a perforated geotextile filter fabric bonded to } \\
\text { entangled polymetric filaments (coils) attached on the underside }(1.5 \mathrm{~cm} \text { thick) }\end{array}$} \\
\hline Root barrier & \multicolumn{2}{|c|}{ XeroFlor XF113 root barrier consisting of 30 mil low density polyethylene (LDPE) } \\
\hline Insulation & \multicolumn{2}{|c|}{ Two layers of extruded polystyrene } \\
\hline $\begin{array}{l}\text { Membrane } \\
\text { protection } \\
\text { board }\end{array}$ & \multicolumn{2}{|c|}{$\begin{array}{c}\text { Multi-ply, semi-rigid core composed of a mineral-fortified asphaltic core formed between } \\
\text { two outside layers of asphalt-impregnated reinforced mats, weather-coated and } \\
\text { covered with a polyethylene anti-stick sheet, manufactured in accordance with ASTM } \\
\text { D6506 }(0.32 \mathrm{~cm} \text { thick })\end{array}$} \\
\hline $\begin{array}{l}\text { Roofing } \\
\text { membrane }\end{array}$ & \multicolumn{2}{|c|}{ Coal tar built-up roofing membrane } \\
\hline Roof slab & \multicolumn{2}{|c|}{ Structural concrete deck } \\
\hline
\end{tabular}
of approximately $67 \mathrm{~m}^{2}$. The remainder of the roof covers $165 \mathrm{~m}^{2}$ and was installed by laying out pregrown vegetated XF301 sedum mats which consisted of the carrier containing at least $5 \mathrm{~cm}$ of a proprietary substrate (XeroTerr $\AA$, XeroFlor America, LLC, Durham, NC) consisting of a combination of $85 \%$ heat expanded slate with a gradation of $<0.5 \mathrm{~cm}$ (PermaTill, Carolina Stalite, Salisbury, NC) and $15 \%$ organic matter (compost). On the deeper part of the roof, herbaceous perennials and grasses were planted in the $20 \mathrm{~cm}$ deep substrate. Physical properties of the substrate were reported in the study of Getter et.al. [3]. Bulk density was $1.17 \mathrm{~g} / \mathrm{cm}^{3}$, capillary pore space was $20 \%$, non-capillary pore space was $21 \%$, and the water holding capacity at $0.01 \mathrm{MPa}$ was $17 \%$. 

kamtschaticum, S. refexum, and S. spurium. The deeper section of the roof consisted of a mixture of 17 herbaceous perennials and grasses native to Michigan and included Allium cernuum, Anemone virginiana, Asclepias tuberosa, Aster laevis, Aster olentangiensis, Campanula rotundifolia, Coreopsis lanceolata, Echinacea purpurea, Geum triflorum, Liatris aspera, Monarda fistulosa, Penstemon hirsutus, Tradescantia ohiensis, and the grasses Eragrostis spectabilis, Koeleria macrantha, Schyzachyrium scoparius, and Sporobolus heterolepis (Wildtytpe Nursery, Mason, MI). All plants were installed October 8-10, 2011. A controlled release fertilizer (Osmocote Plus X $15 \mathrm{~N}-9 \mathrm{P}_{2} \mathrm{O}_{5}-12 \mathrm{~K}_{2} \mathrm{O} 5-$ month release, Everis International BV) was applied the following spring at a rate of $11.0 \mathrm{~g} / \mathrm{m}^{2}$ and irrigation was supplied with an overhead oscillating garden sprinkler (Melnor, Inc., Winchester, VA) through a hose on an as-needed basis during 2012 to aid in establishment. Thereafter, no supplemental irrigation was applied so plants had to rely on natural rainfall. Since the plants were installed in 2011, the roof was well established and had reached near $100 \%$ plant coverage by the time data collection commenced on June 24, 2013.

\subsection{Experimental setup and instrumentation}

Both roof sections were instrumented with heat flux sensors, thermocouples, moisture sensors, and infrared sensors (Fig. 2). A total of three heat flux, nine temperature, three moisture, and two infrared sensors were placed at various locations within the roof profile for each roof type. Ambient weather conditions were recorded by a weather station located on the roof. All data were continuously recorded on a CR10X Datalogger (Campbell Scientific, Inc., Logan, UT) while utilizing a series of AM25T 25-Channel Solid-State Multiplexors (Campbell Scientific, Inc., Logan, UT). Data were collected for the period between June 24, 2013 and May 23, 2014. 


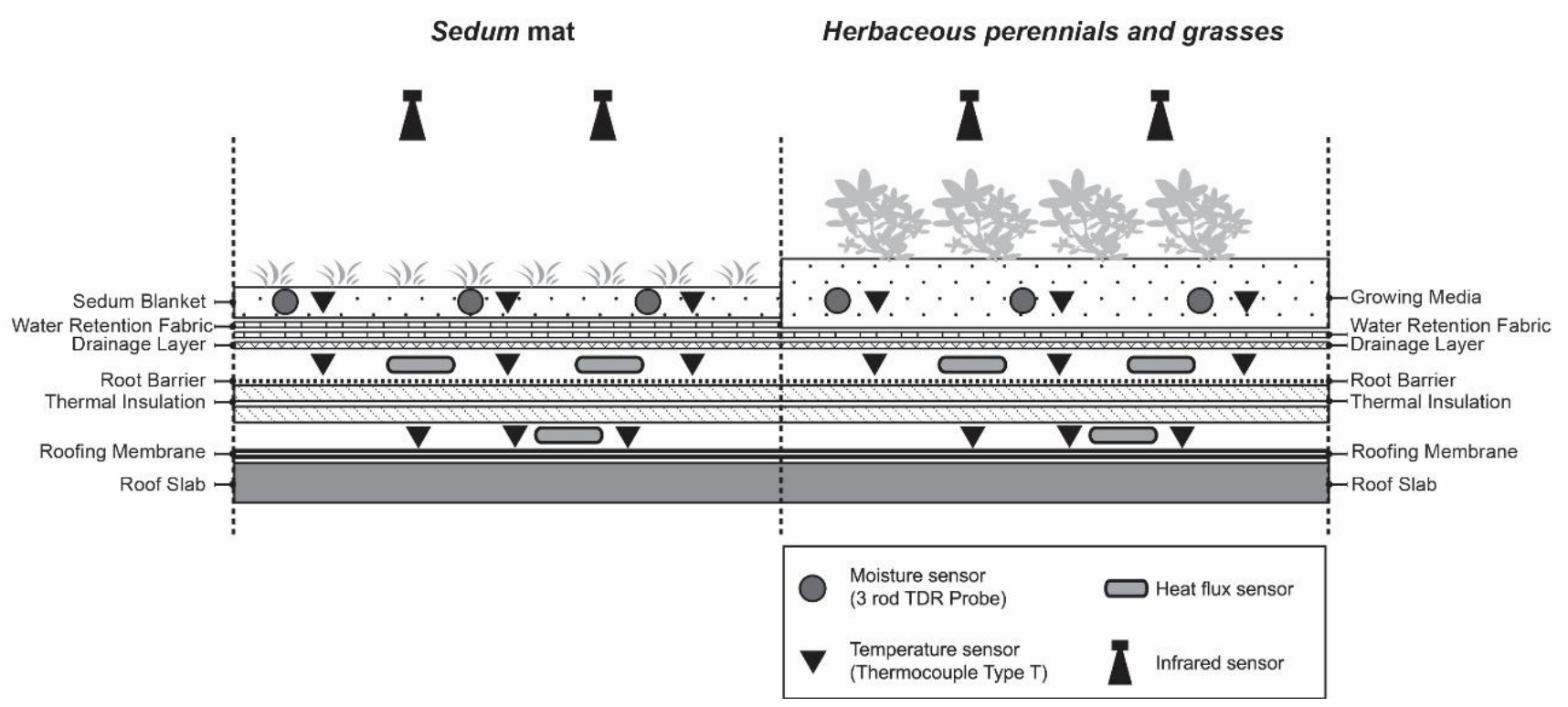

180

181

182

183

184

185

186

187

188

189

190

191

192

193

194

195

196

197

198

199

200

Fig. 2. Locations of heat flux, temperature, moisture, and infrared sensors in the roof layers.

Universal heat flow sensors (Concept Engineering, Old Saybrook, CT) were placed at the water proofing membrane and top of the insulation layers to measure the heat flux through the roofing membrane and thermal insulation (Fig. 2). The sensor, which was deployed so that negative and positive readings would measure heat entering and leaving the building, respectively, had an accuracy of $\pm 5 \%$. Thermocouples (Campbell Scientific Type T105T-L) measured temperature values for each layer (roofing membrane, root barrier and growing substrate). During spring, we were unable to measure the heat flux through the roofing membrane under the herbaceous portion because of sensor malfunctions. The heat flux sensors at the roofing membrane and insulation stopped responding on January 22 and April 28, respectively. The three thermocouples at each layer were spaced horizontally $1 \mathrm{~m}$ apart from each other. Thermocouple accuracy ranged from $\pm 0.365^{\circ} \mathrm{C}, \pm 0.1^{\circ} \mathrm{C}$, and $\pm 0.25^{\circ} \mathrm{C}$ for temperatures in the range of $-73^{\circ} \mathrm{C}, 20^{\circ} \mathrm{C}$, and $50^{\circ} \mathrm{C}$, respectively. Roof surface temperatures were measured by four infrared sensors with an accuracy of $\pm 1 \%$ and $2: 1$ field of view ratio (OS211-LT Series IR Temperature Sensors, Omega Engineering, Stamford, CT). Two infrared sensors were located $1 \mathrm{~m}$ above the roof surface for each roof portion, spaced $1 \mathrm{~m}$ apart.

Time-Domain Reflectometer moisture probes (Moisture Sensor CS605-L 3-rod TDR probeRG58, Campbell Scientific) in each section were installed horizontally into the Sedum blanket and 20 $\mathrm{cm}$ deep in the substrate. The moisture sensors had a rod measure of $30 \mathrm{~cm}$ in length, $0.475 \mathrm{~cm}$ in diameter, and a radius of influence of $50 \mathrm{~mm}$. The calibration process was based on multiple studies using PCTDR software (Campbell Scientific, Inc., Logan, UT) [32-34]. 

Inc., Logan, UT) with an accuracy of $\pm 1 \%,+0$ and $-2.5 \%$, and +0 and $-3.5 \%$ for rainfalls $<25.4 \mathrm{~mm} / \mathrm{h}$, 25.4-50.8 mm/h, and 50.8-76.2 mm/h, respectively. Precipitation data were polled every minute, then totaled and reported at half-hour intervals. In the winter months, precipitation data were excluded from the dataset due to the inability of measuring solid precipitation. Other meteorological parameters such as wind speed, wind direction, solar radiation, air temperature, and relative humidity were recorded by sensors mounted on a weather station (CM10 Tripod, Campbell Scientific, Inc., Logan, UT). Wind speed and direction was recorded with a 03001 R.M. Young Wind Sentry Set (Campbell Scientific, Inc., Logan, UT) which had an accuracy of $\pm 0.5 \mathrm{~ms}^{-1}$ for wind speed and $\pm 5^{\circ}$ for wind direction. Air temperature and relative humidity measurements were performed with CS500 Temperature and Relative Humidity Probe (Campbell Scientific, Inc., Logan, UT) which had an accuracy of $\pm 3 \% \mathrm{RH}$ at $20^{\circ} \mathrm{C}$ between 10 to $90 \%$ of $\mathrm{RH}$. The solar radiation sensor used in this study (LI200X Pyronometer, Campbell Scientific, Inc., Logan, UT) had a typical accuracy of $\pm 3 \%$. The datalogger was programmed using Loggernet Edlog Software (Campbell Scientific, Inc., Logan, UT). All data were sampled every 30 minutes. These data were averaged and reported at hourly and daily intervals. 16.2.2 (Minitab Inc., State College, PA). All data were checked for normality prior to analysis of variance by using the Kolmogorov-Smirnov test (Minitab Inc., State College, PA).

\section{Results and Discussion}

During the research period, average monthly maximum and minimum ambient air temperatures recorded $1.5 \mathrm{~m}$ above the roof surface ranged from $-12.1^{\circ} \mathrm{C}$ in January to $28.2{ }^{\circ} \mathrm{C}$ in July. These temperatures were similar to temperature data obtained $1.5 \mathrm{~m}$ above ground level at a nearby weather station (Michigan Enviro-weather Network, East Lansing) which ranged from $-15.7^{\circ} \mathrm{C}$ to $28.4^{\circ} \mathrm{C}$ (Fig. 3). Ambient air temperatures $1.5 \mathrm{~m}$ above the green roof were warmer during the winter than at ground-level, but there was little difference during the rest of the year. The hottest day of the study period was July 19,2013 , when the daily average ambient temperature reached $28.3^{\circ} \mathrm{C}$ and the coldest temperature of $-19.4{ }^{\circ} \mathrm{C}$ was recorded occurred on January 7,2014 . Monthly precipitation patterns was also similar. Precipitation totaled $580.1 \mathrm{~cm}$ at the Enviro-weather station and $530.6 \mathrm{~mm}$ 
on the roof during the measurement period (Fig. 4). Due to the inability of measuring snow during the winter months, precipitation data represented in the study on the roof only includes rainfall. The heaviest rain event of $53.8 \mathrm{~mm}$ occurred October 5,2013 . The longest period of drought was nine days between August 13 and August 21, 2013.

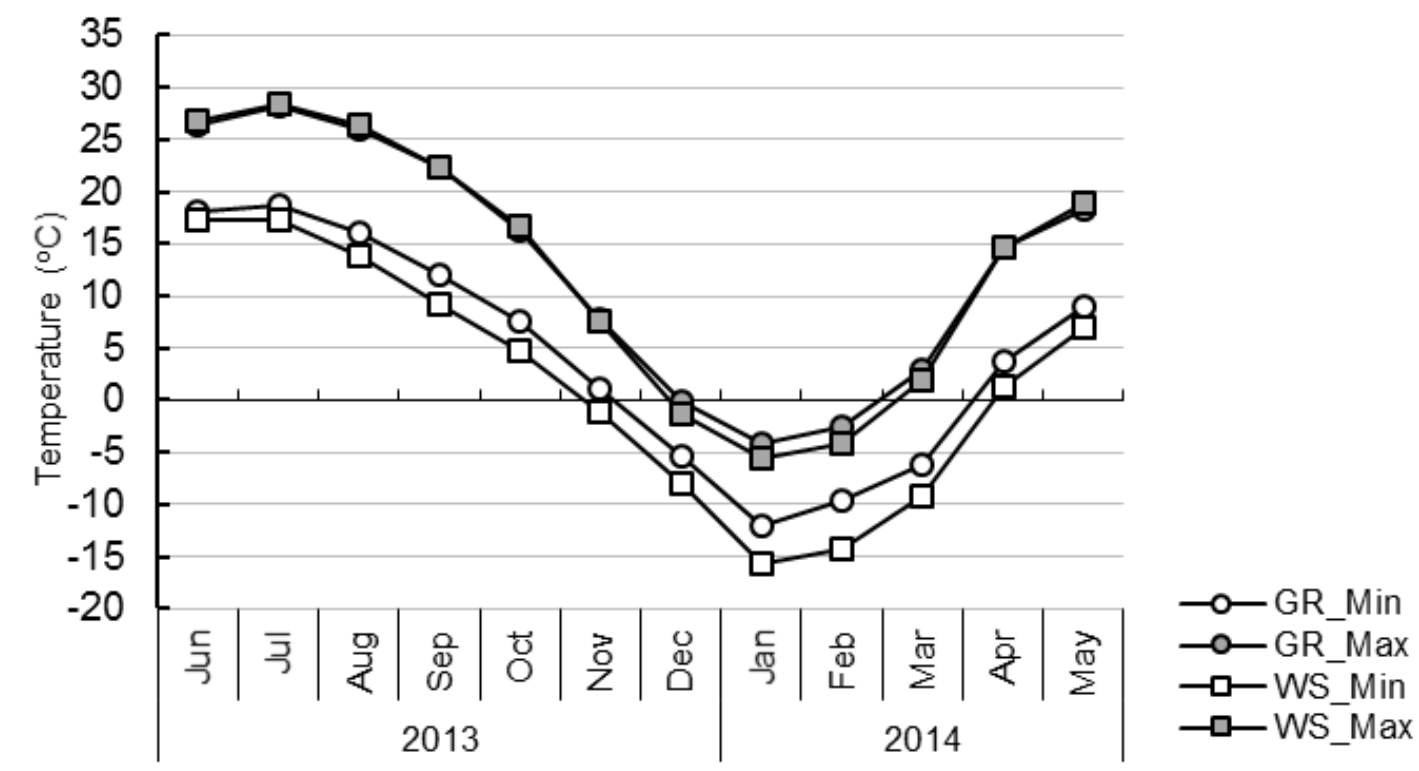

Fig. 3. Comparison of monthly average maximum and minimum air temperatures $\left({ }^{\circ} \mathrm{C}\right)$ on study area (GR) and nearby Enviro-weather (Michigan Automated Weather Network's) Weather Station (WS).

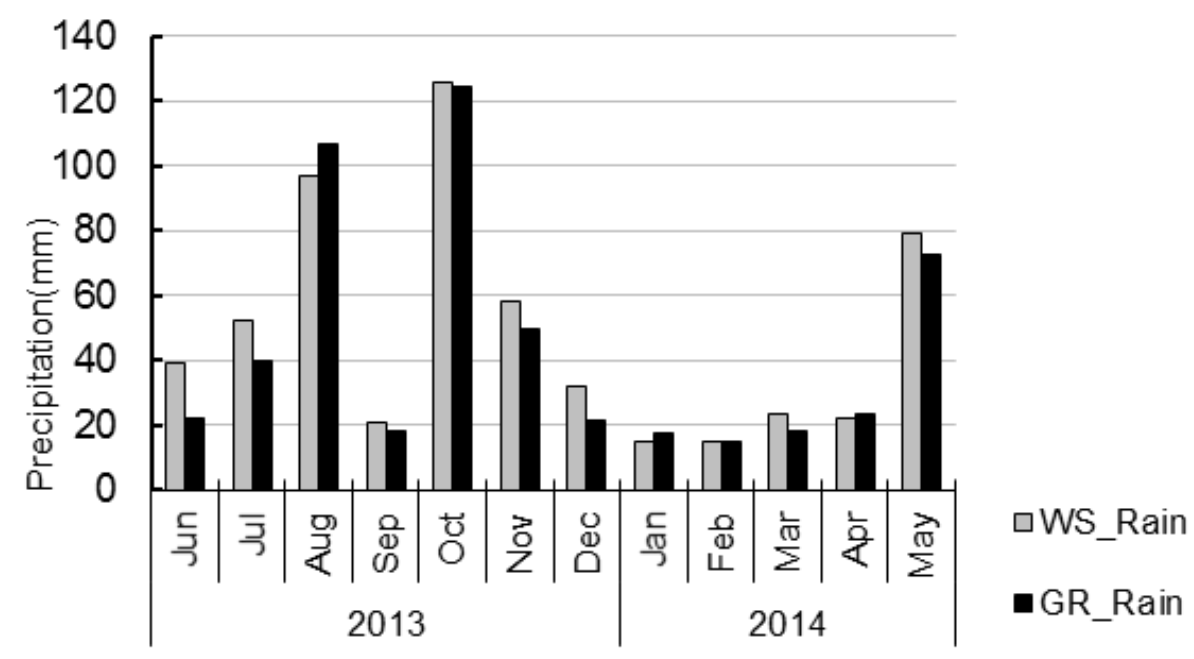

Fig. 4. Comparison of monthly total precipitation recorded on the study area (GR) and at a nearby Enviro-weather (Michigan Automated Weather Network's) Weather Station (WS) during the study period. 


\subsection{Summer}

Most of the notable differences in temperatures and heat flux through the various layers of the roofing envelope occurred during the summer season (June 24 to August 30). The surface temperature on both the sedum and herbaceous perennial green roofs generally mirrored the ambient air temperature. The major exception was on sunny days when surface temperatures and the range in temperatures on both roofs were often higher (Fig. 5). This was especially true for the sedum roof. Daily surface temperature fluctuations on the sedum portion were as much as $32.8^{\circ} \mathrm{C}$, whereas they ranged up to $21.2{ }^{\circ} \mathrm{C}$ on the herbaceous roof. Thermal protection provided by herbaceous plants was greater, presumably due to its deeper growing substrate and shade provided by the plant canopy. During the afternoon, the surface of the sedum roof was as much as $13{ }^{\circ} \mathrm{C}$ warmer than the surface of the herbaceous roof. The spike in temperatures occurred shortly after noon when the area being measured passed from the shade into the sun and these readings remained higher through late afternoon. Over the entire season, the daily average surface temperature of the sedum roof was $4^{\circ} \mathrm{C}$ warmer than the herbaceous portion. This agrees with the work of Blanusa et al. [29] who found that the leaf surface temperature was lowest for the broadleaf Stachys byzantina compared to a mix of sedum. In contrast, Maclvor et al. [26] observed that the lowest surface temperatures $\left(2^{\circ} \mathrm{C}\right.$ lower) and air temperatures $15 \mathrm{~cm}$ above the surface $\left(1.5^{\circ} \mathrm{C}\right.$ lower) occurred for a sedum plant community compared to a grasses and wildflower meadow mix. When the meadow vegetation was irrigated it performed as well as the unirrigated sedum.

Temperatures of the substrate and at the top of the roofing insulation followed the same general trend as surface temperature. However, diurnal fluctuations in temperature on sunny days were much greater under the sedum due to its shallow substrate depth. Diurnal substrate temperature differences increased up to $27.5^{\circ} \mathrm{C}$ in the sedum, but only fluctuated by a maximum of $9{ }^{\circ} \mathrm{C}$ in the herbaceous portion. The shallower substrate of the sedum dried out faster and the limited substrate moisture produced the higher temperature fluctuations. As with surface temperature, peak substrate temperatures occurred during the afternoon and differences were sometimes as much as $14{ }^{\circ} \mathrm{C}$ between these two roof systems. However, temperatures of the substrate and at the top of the insulation tended to be lower during the night and morning hours under the sedum. The diurnal pattern observed here agrees with the work of Franzaring et al. [25] who recorded the highest summer 
substrate temperatures during the afternoon, whereas the substrates retained this heat during the night such that these temperatures were actually higher than the night time ambient air temperatures. Measurements below the insulation at the roofing membrane showed no significant differences in temperature between the two roof types. Since the green roof was installed on an inverted roof, the insulation layer above the roofing membrane limited extreme temperature fluctuations, thus demonstrating one of the advantages of inverted roofs. Heat penetrating (negative flux) through the sedum portion of the roof was consistently greater (inward or more negative) in magnitude than the herbaceous section during the afternoon (Fig. 5). However, during the night and early morning, heat gain (inward and negative) was greater on the herbaceous roof, especially on cloudy and rainy days. Overall, heat gain and the magnitude of temperature change on the sedum was higher on sunny days than on cloudy or rainy days due to higher solar radiation levels, higher ambient air temperatures, lower precipitation, and limited substrate moisture. Heat flux correlated with the moisture level of the growing substrate and precipitation. Increases in substrate volumetric moisture contributed to the removal of heat energy from the roof and building (data not shown) through evapotranspiration. In drought periods heat gain into the building was greater due to lack of evaporation from the substrate. 

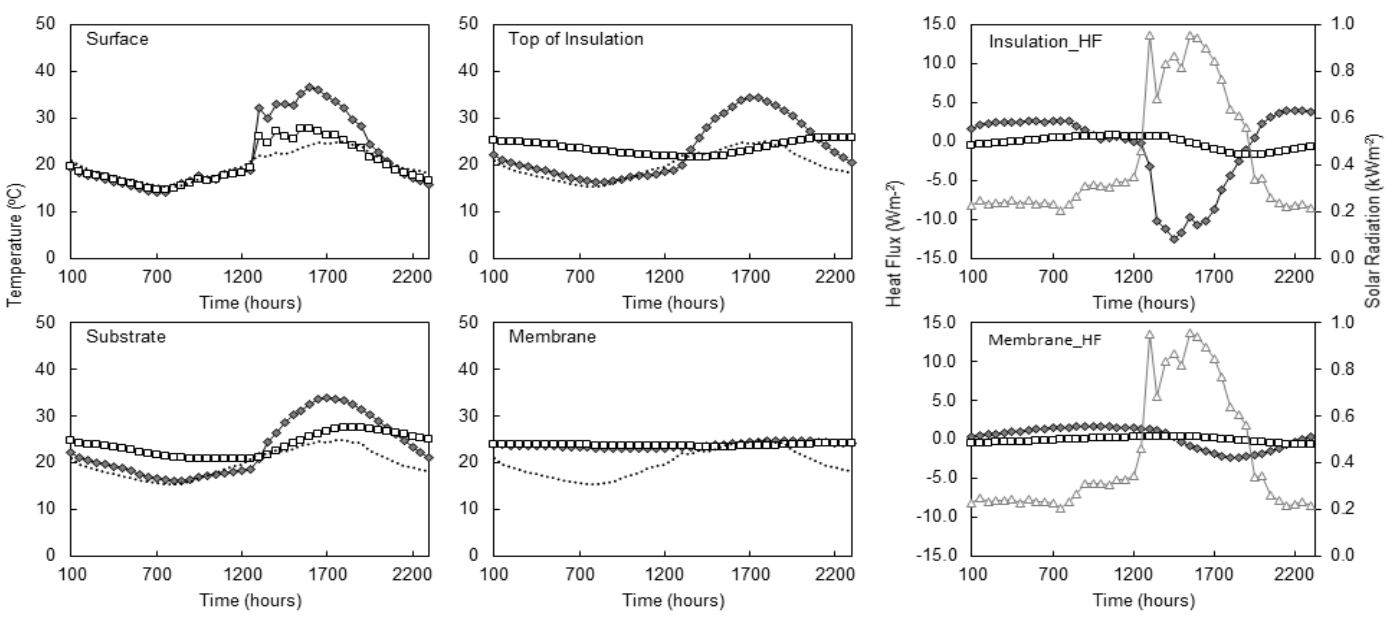

(B) Summer Cloudy (31August2013)
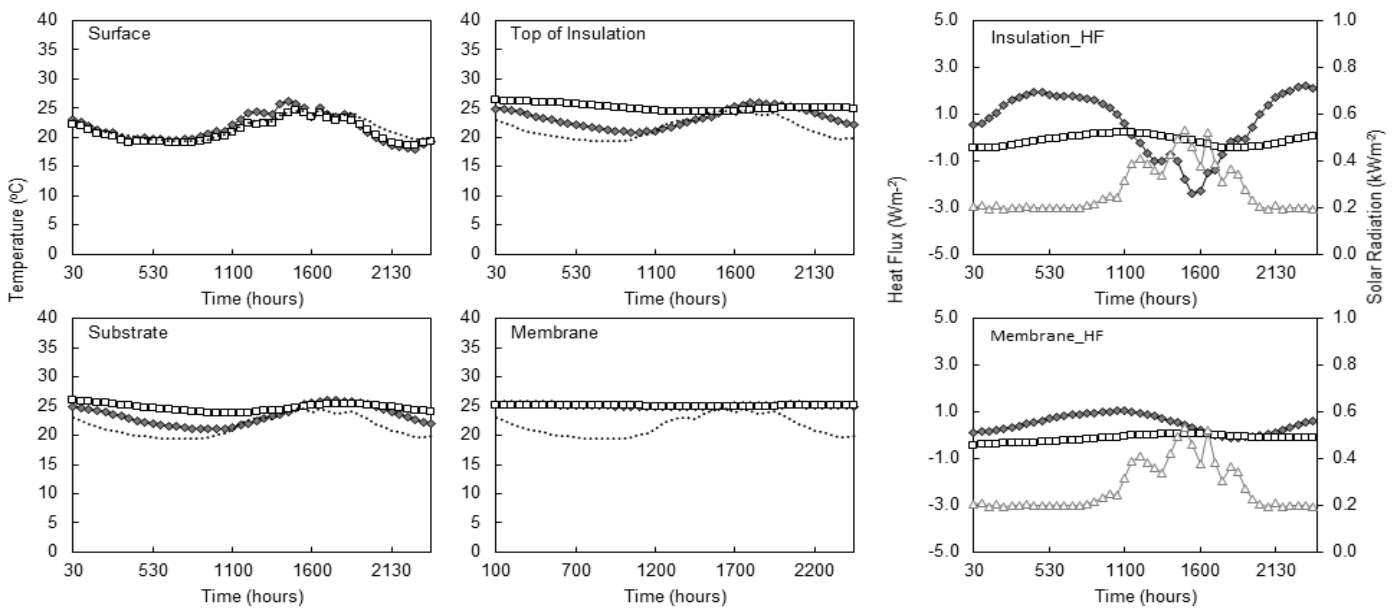

(C) Summer Rainy (27August2013)
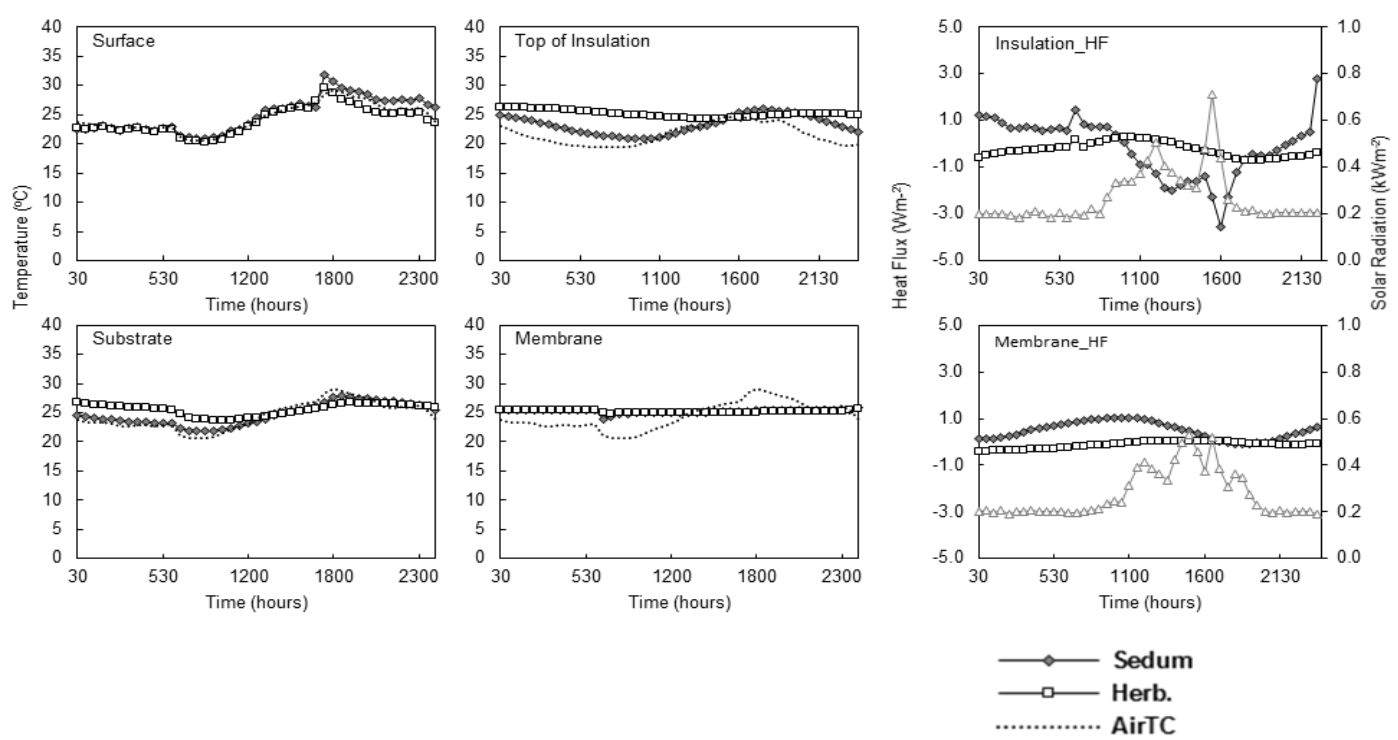

$\triangle$ SolarRad_kW (avg)

Fig. 5. Thermocouple and heat flux data over 24-h periods for various environmental conditions during the summer season. Time shown in military time. Data symbols only shown on every other data point building, respectively. 
On a representative rainy summer day (August 27, 2013), volumetric moisture content of the

297

298

299

300

301

302

303

304

305

306

307

308

309

310

311

312

313

314

315

316

317

318

319

320

321

322

323

324

sedum portion rose immediately to 0.13 after a rain event, whereas the deeper substrate in the herbaceous perennial and grasses increased steadily throughout the day, but only reached 0.07 . As precipitation significantly affects moisture content it also affects the heat balance of the roof portions. When the volumetric moisture increased with the beginning of precipitation at 7:30 $\mathrm{h}$ and after precipitation stopped at 9:00 h, heat flux for the sedum portion was outward (loss) due to evaporation. Heat flow under the herbaceous portion was steadier throughout the day, gaining a small amount of heat until precipitation began at 7:30 $\mathrm{h}$. Then during the rain event $(7: 30-9: 00 \mathrm{~h})$, the inward heat flow stopped and reversed to outward flow six hours after precipitation. Even though the larger volume of substrate in the herbaceous portion could retain more water, it was slower to change in temperature. The water retention ability of the deeper substrate in the herbaceous portion was evident in consecutive rainless days. On the sedum portion, volumetric moisture content sharply decreased in drought periods during summer while the deeper portion retained more water.

\subsection{Autumn}

During autumn (September 1 - November 30), diurnal patterns for surface, substrate, insulation, and membrane temperatures as well as heat flux were similar to those observed in summer (Fig. 6). Although overall temperatures were lower, the amplitude of change was sometimes higher due to much lower night temperatures. As for summer, substrate and insulation temperatures were higher in the sedum portion during the afternoon, but were warmer in the perennials the rest of the day and night. This was the case on both sunny and cloudy days, but not during rain events. During the afternoon, substrate temperatures were up to $4.1{ }^{\circ} \mathrm{C}$ warmer in the sedum, whereas during the early and late hours of the day the opposite was true: the sedum was up to $5.3^{\circ} \mathrm{C}$ cooler. Roof membrane temperatures were nearly identical to summer temperatures even though ambient air temperatures were significantly lower. The temperature distribution on the membrane was almost even under both roof surfaces and significantly lower than the upper layers due to the insulation.

Greater fluctuations in temperatures were observed during autumn, especially in September and October due to larger differences between day and night temperatures. In September, roof surface temperatures on the sedum portion fluctuated by as much as $45^{\circ} \mathrm{C}$, whereas, the herbaceous 
part only fluctuated by a maximum of $30^{\circ} \mathrm{C}$. Similar fluctuations were observed on the layers beneath. By the end of autumn, with the steady decrease in solar radiation and ambient air temperatures, the temperature variations were lower. Temperature fluctuations at various points in the roof profile show that both roof types have an ability to protect the roofing membrane from extreme temperature changes. However, even though temperature fluctuations in the herbaceous part of the roof were lower than the sedum portion it appears that the largest factor in protecting the membrane was the roof insulation.

In the afternoon hours, heat flow was into the building on the sedum portion of the roof. Heat tended to leave the roof over the remainder of the day. On the herbaceous perennial and grasses part, there was no significant heat transfer in either direction. On a specific autumn day (October 5) when the heaviest rain event of the season occurred $(53.8 \mathrm{~mm})$, heat flux out of the building through the sedum portion of the roof was extreme (Fig. 6). This was especially evident early in the day when the most intense rainfall occurred. This high heat loss from the sedum portion reduced the temperature of the roofing membrane considerably compared to the deeper herbaceous portion of the roof.

On another rainy day (October 31), volumetric moisture content had an impact on temperature values at the insulation and membrane and correlated with heat flux. As volumetric moisture increased in the substrate, heat flux occurring at the roof membrane under both roof portions was out of the building (heat loss). Heat flux peaked at $500 \mathrm{~h}$ when the highest precipitation rate was occurring. When the rain stopped, the sedum portion of the roof drained quickly and heat flux through the roofing membrane started to diminish. However, the heat flux through the roofing membrane under the herbaceous portion of the roof remained relatively stable. 
(A) Autumn Sunny (3September2013)
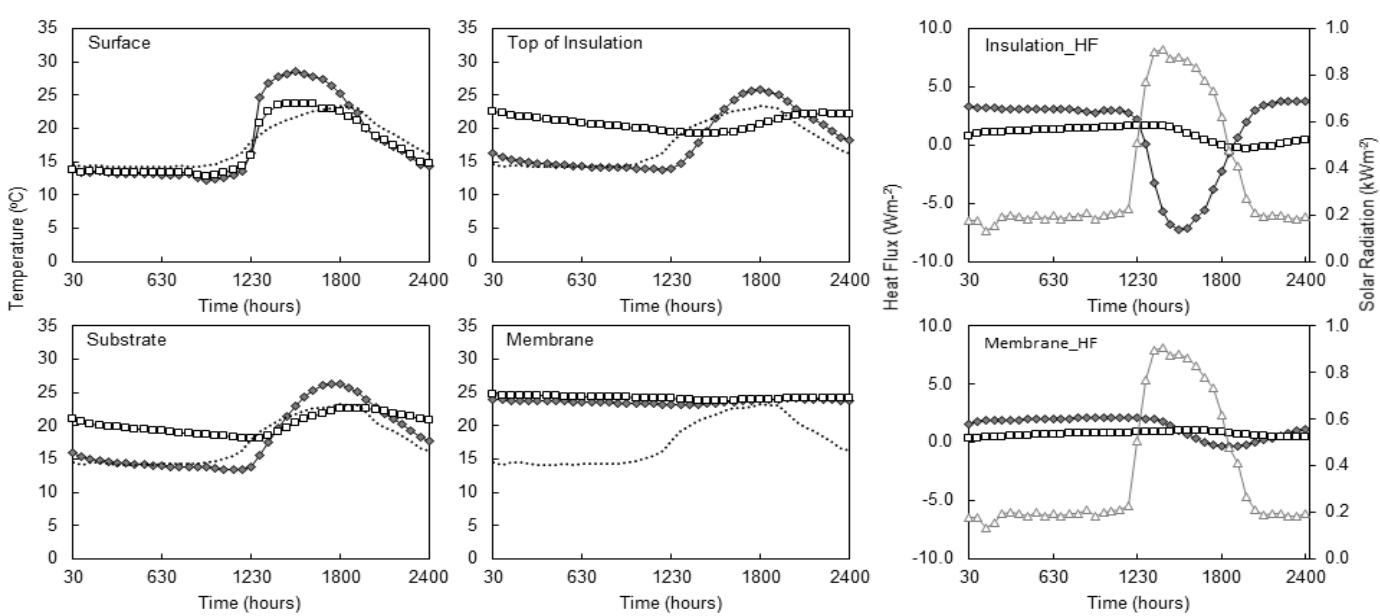

(B) Autumn Cloudy (15September2013)
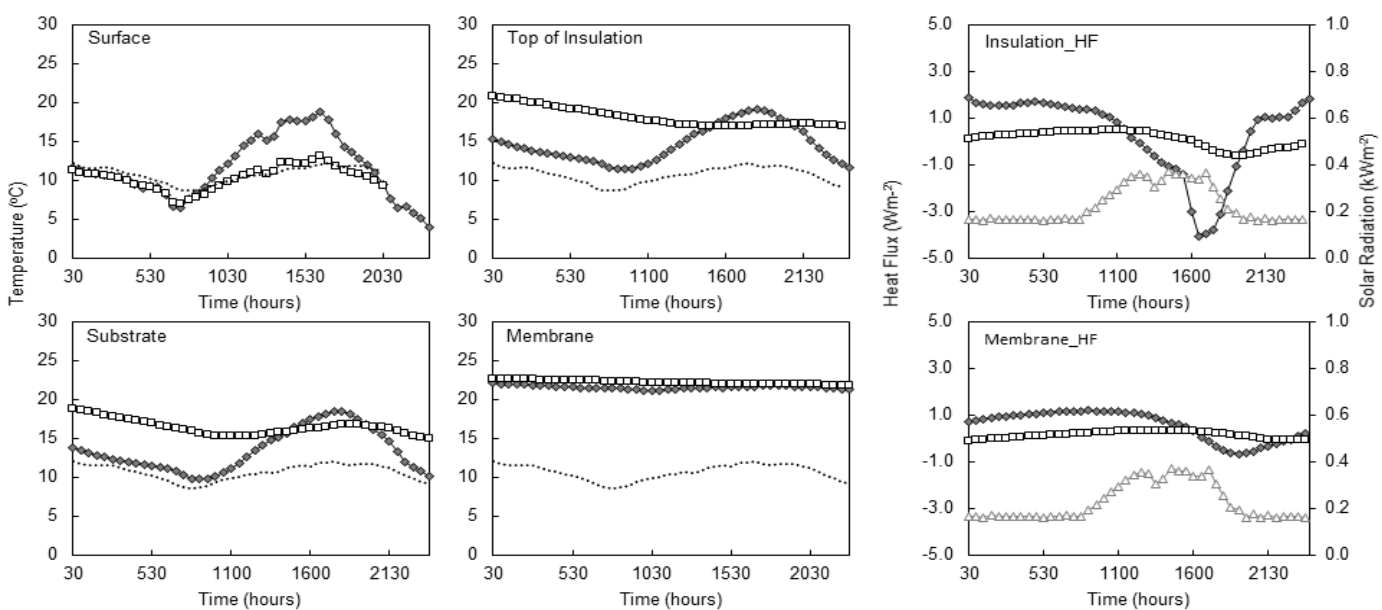

(C) Autumn Rainy (5October2013)
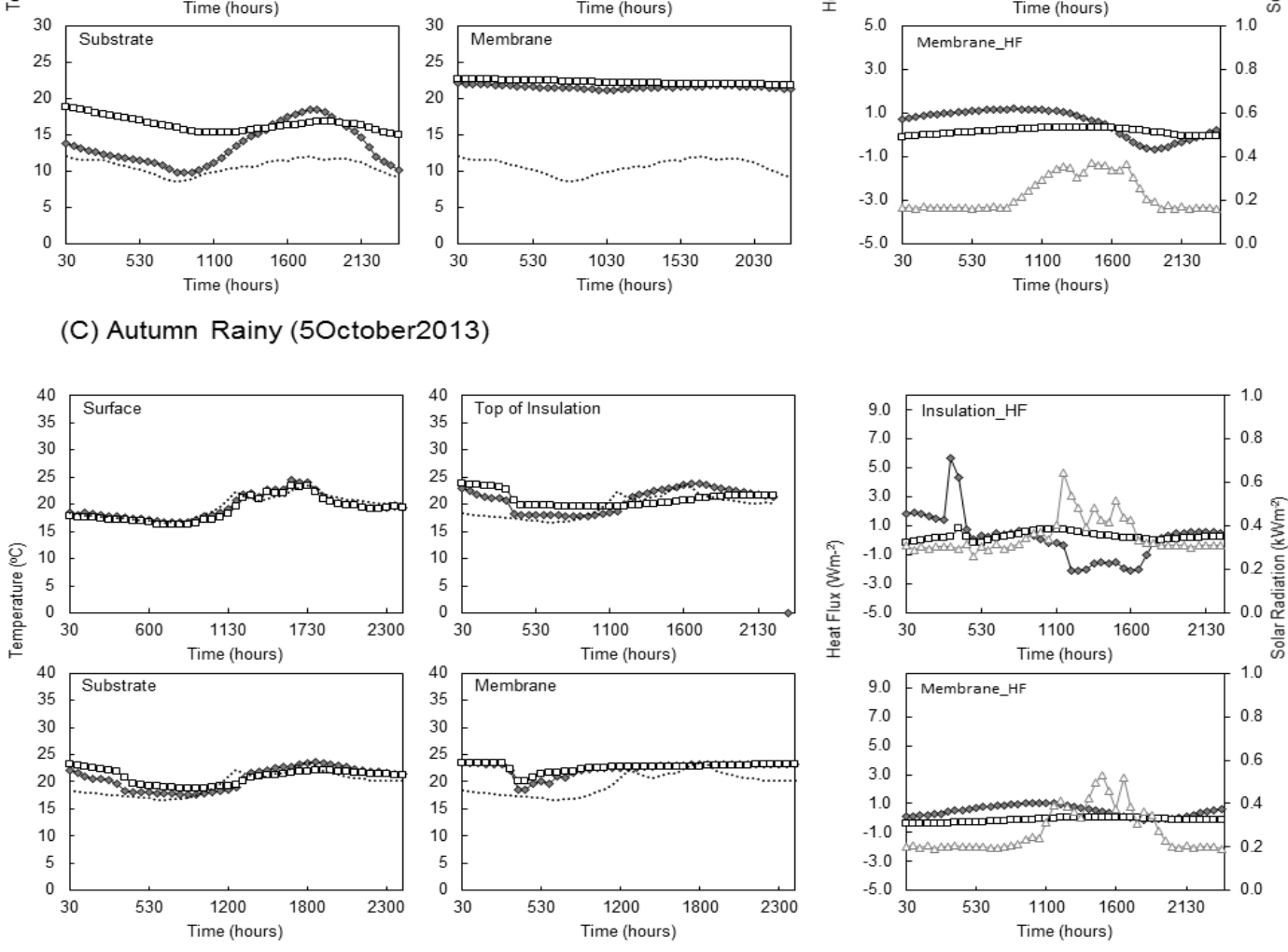

Fig. 6. Thermocouple and heat flux data over 24-h periods for various environmental conditions during the summer season. Time shown in military time. Data symbols only shown on every other data point for clarity of graphing. Negative and positive heat flux readings represent heat entering and leaving the building, respectively. 
During winter (December 1 - February 28), roof surfaces were covered with snow most of the season. Nearly identical surface temperatures were observed on the roof portions (Fig. 7). This is not surprising as snow cover acts as an insulation layer during the winter [15, 27, 35, 36]. However, substrate temperatures of the herbaceous portion were up to $10 \stackrel{\circ}{C}$ warmer during the coldest time of the year in January. As with other seasons, solar radiation on sunny days produced large fluctuations in substrate and insulation temperatures on the sedum roof, but not for the herbaceous roof. Substrate depth influenced the heat balance on the roof by reducing the solar energy gain of the layers beneath the green roof. On both roofs, heat flux was outward (heat loss), but was generally more pronounced from the sedum as it lost more heat. Also, when it could be measured (water not frozen), volumetric moisture content was higher in the herbaceous portion than the sedum part. recorded in the substrate and above the insulation layer under the sedum were consistently below zero. Meanwhile, above freezing temperatures were observed at the same locations in the herbaceous portion of the roof. These differences may be due to vegetation type as plants with greater biomass (the herbaceous roof in our case) have been shown to trap more snow, reduce substrate temperatures and heat loss, and moderate any fluctuations in heat flux [15, 27]. However, in our study, we did not measure snow depth, but similar results were observed regardless of snow cover, suggesting that snow cover served as a less important factor compared to the substrate depth. Like in summer, temperature differences between the roof portions were not observed at the roofing membrane although the membrane was slightly warmer under the herbaceous perennials. transfer through the sedum portion of the roof was affected more by outside environmental conditions, whereas the herbaceous portion of the roof was stable. The herbaceous portion of the roof reduced heat losses by $61.4 \%$ compared to the sedum portion. At the peak hours of solar radiation, heat loss

378 from the insulation layer of the building decreased under the sedum portion, but not as much as the 379 herbaceous roof. 
(A) Winter Sunny (03January2014)
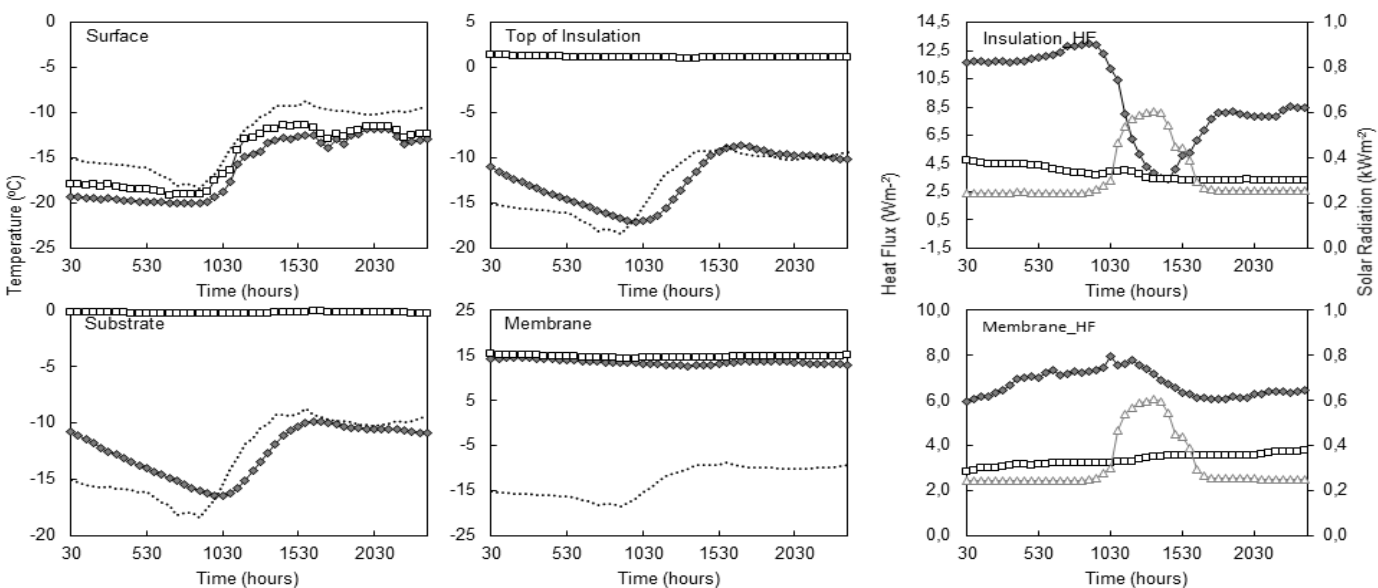

(B) Winter Roof Portions Are Snow Covered (11December2013)
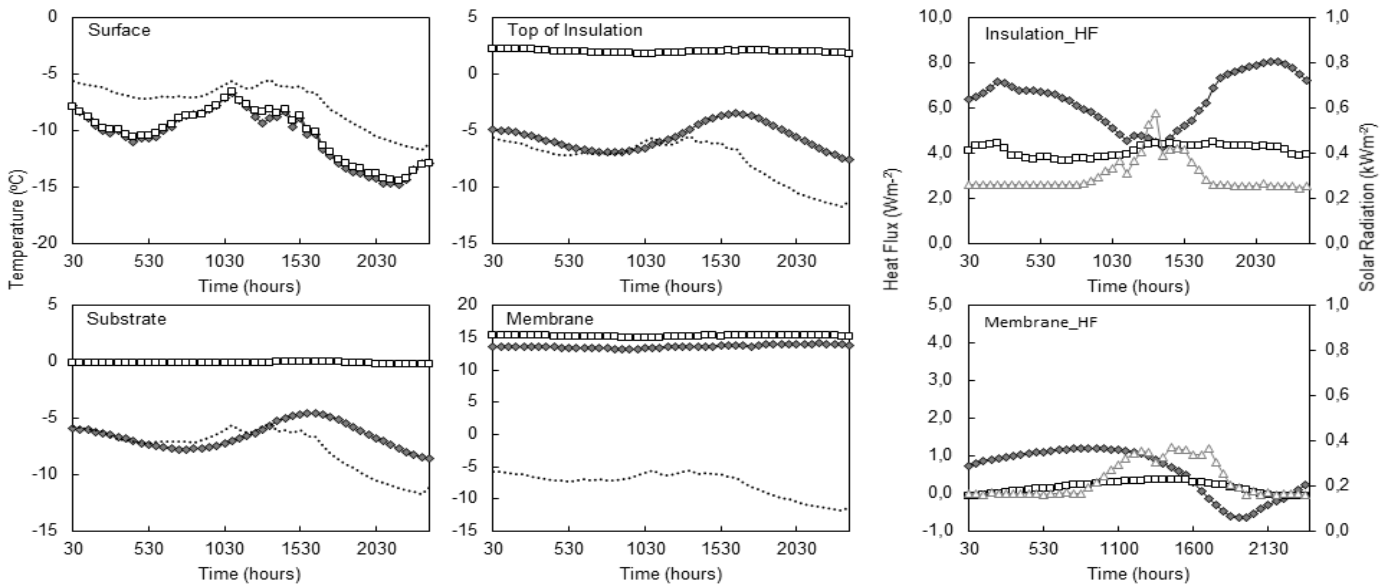

(C) Winter No Snow Cover (31December2013)
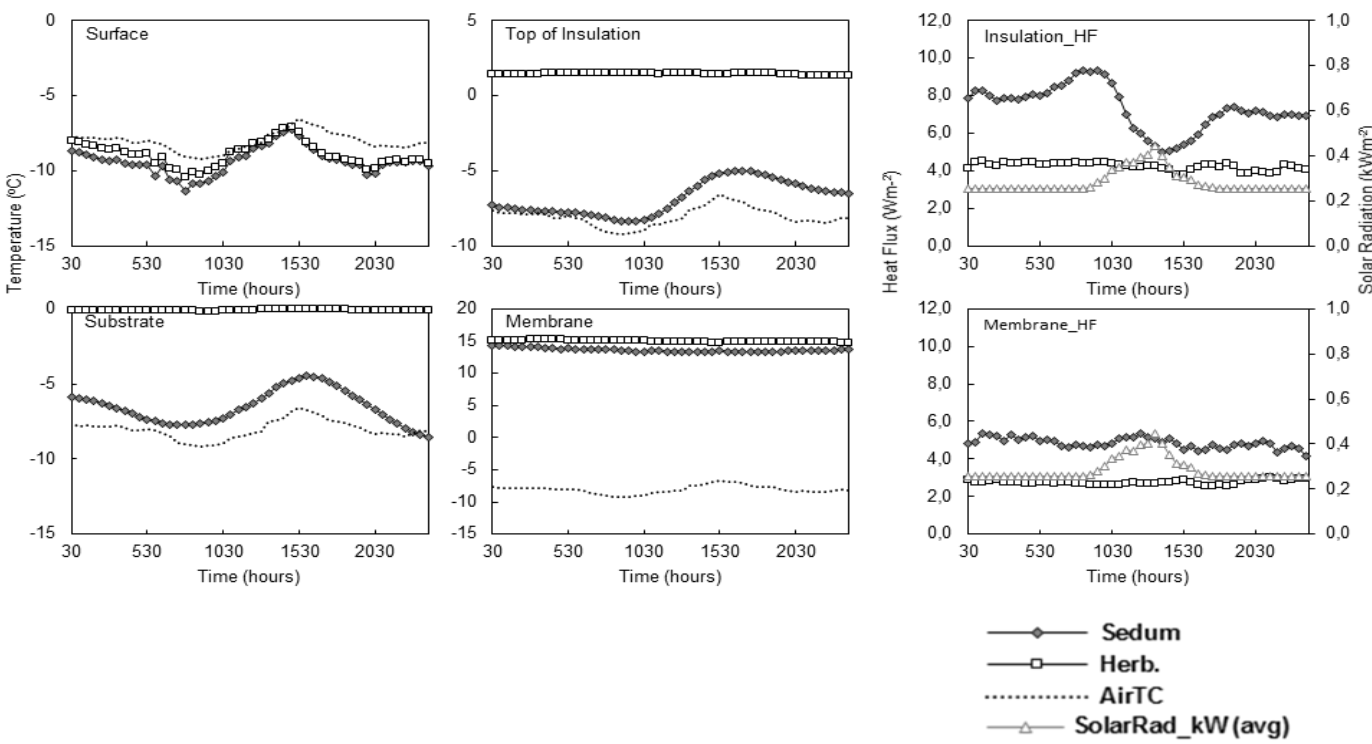

Fig. 7. Thermocouple and heat flux data over 24-h periods for various environmental conditions during the winter season. Time shown in military time. Data symbols only shown on every other data point for clarity of graphing. Negative and positive heat flux readings represent heat entering and leaving the building, respectively. 
Patterns for surface, substrate, top of insulation, and membrane temperatures during the 389 spring season (March 1 - May 31) were similar to autumn (Fig. 8). However, a major difference was 390 that during spring heat flux was generally out of the building (heat loss) instead of into the building as 391 in autumn (heat gain). This difference was likely due to lower air temperatures and higher volumetric moisture content during this time period. During spring, in a total of 83 days in the measurement period, average ambient air temperature was below freezing (with a minimum of $-13^{\circ} \mathrm{C}$ ) for 15 days.

394 The spring season was cold and rainy and solar radiation levels were generally low. Even so, heat flow through the sedum portion was slightly higher than the herbaceous portion. 

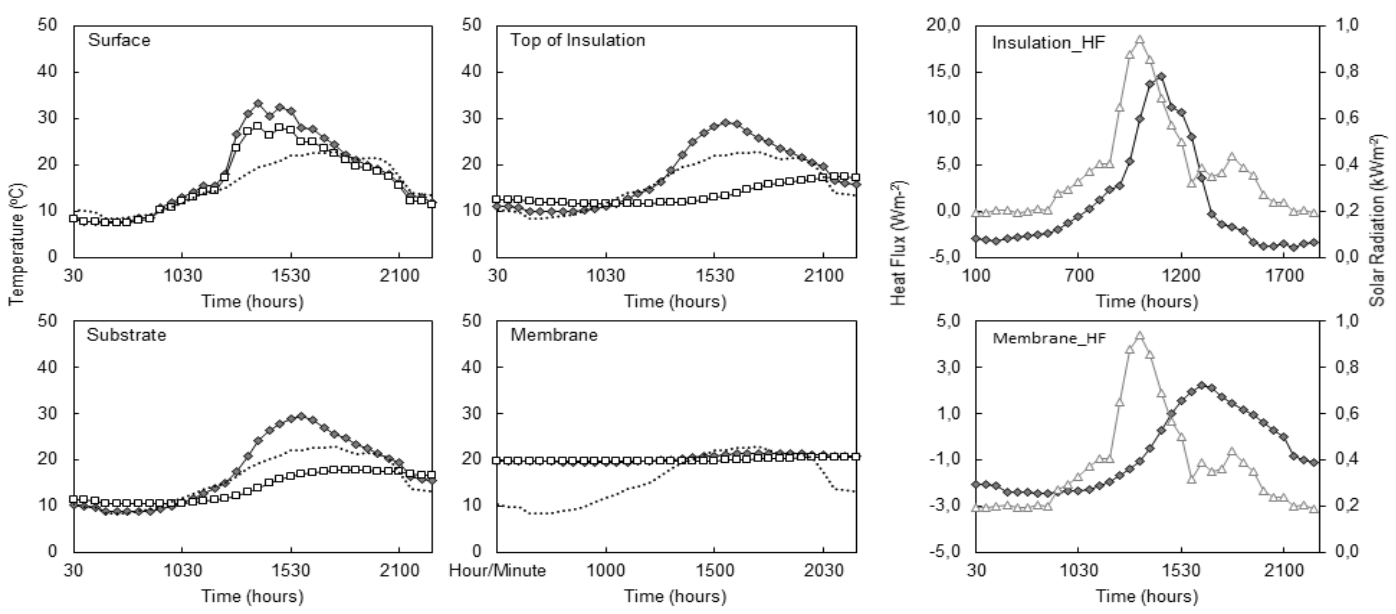

(B) Spring Cloudy (27April2014)
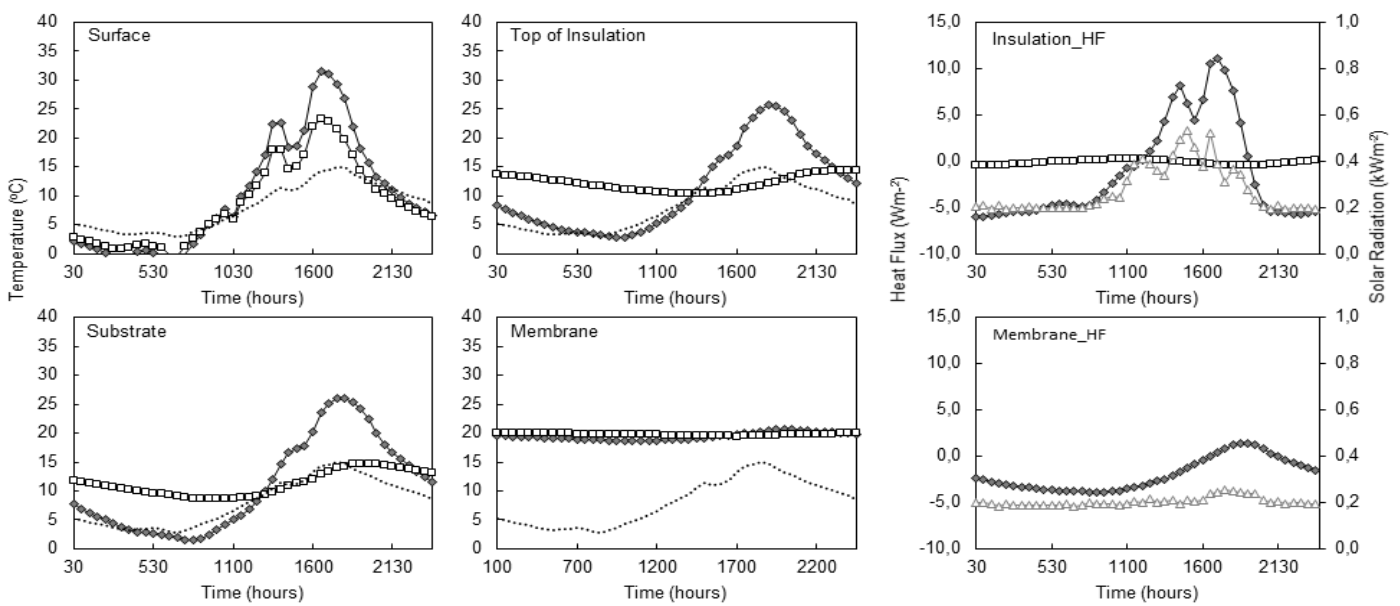

(C) Spring Rainy (12May2014)
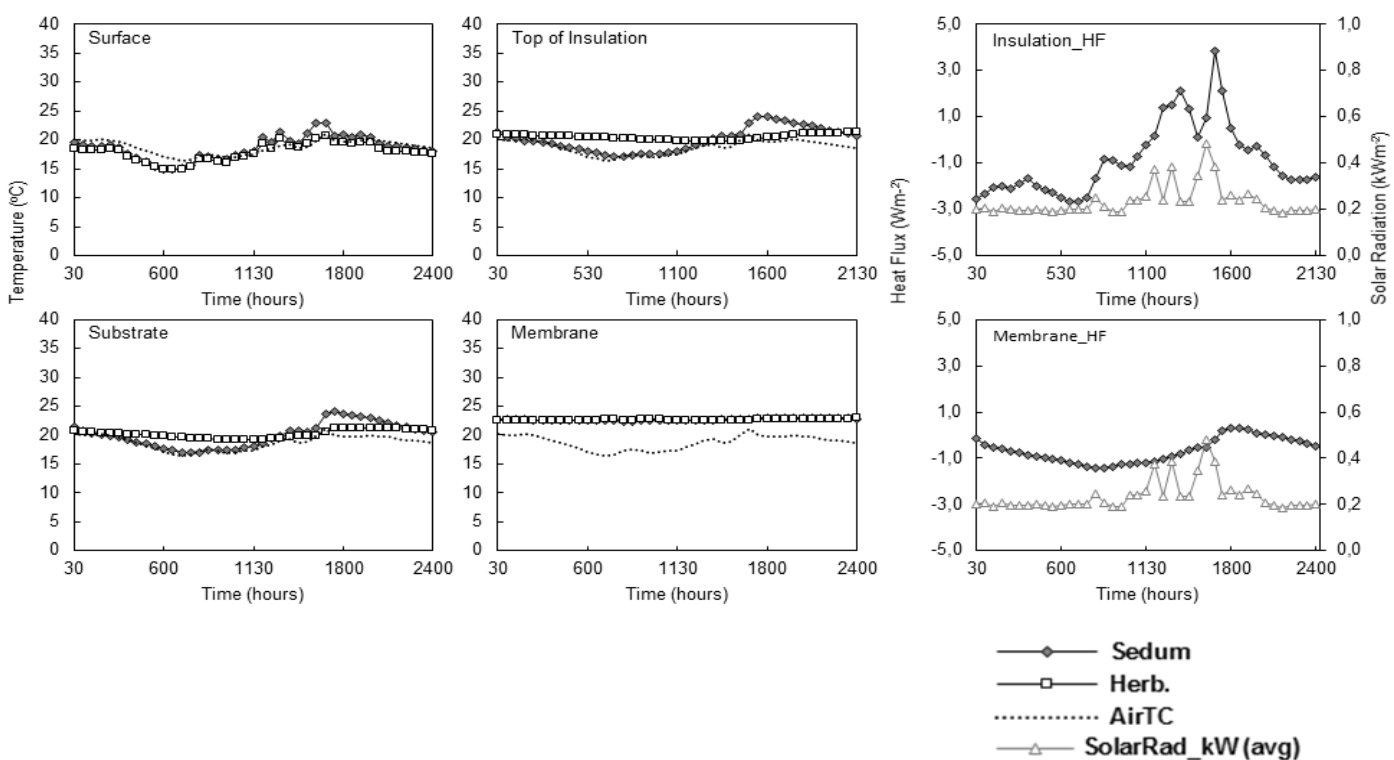

Fig. 8. Thermocouple and heat flux data over 24-h periods for various environmental conditions during the spring season. Time shown in military time. Data symbols only shown on every other data point for clarity of graphing. Negative and positive heat flux readings represent heat entering and leaving the building, respectively. 


\subsection{Annual pattern}

Over the course of a year (June 2013 - May 2014), average maximum and minimum roof

404

405

406

407

408

409

410

temperatures and heat fluxes demonstrate the differences between the two roof systems that varied in substrate depth and vegetation type (Fig. 9). Surface temperatures were relatively equal throughout except during summer when the sedum roof was warmer. Temperatures in the substrate and at the top of the insulation were similar, but more extreme temperatures were recorded in the sedum compared to the herbaceous perennials. There were minimal differences between roof types at the membrane, again suggesting that vegetation and substrate depth are not a major factor on an inverted roof as long as adequate insulation exists.
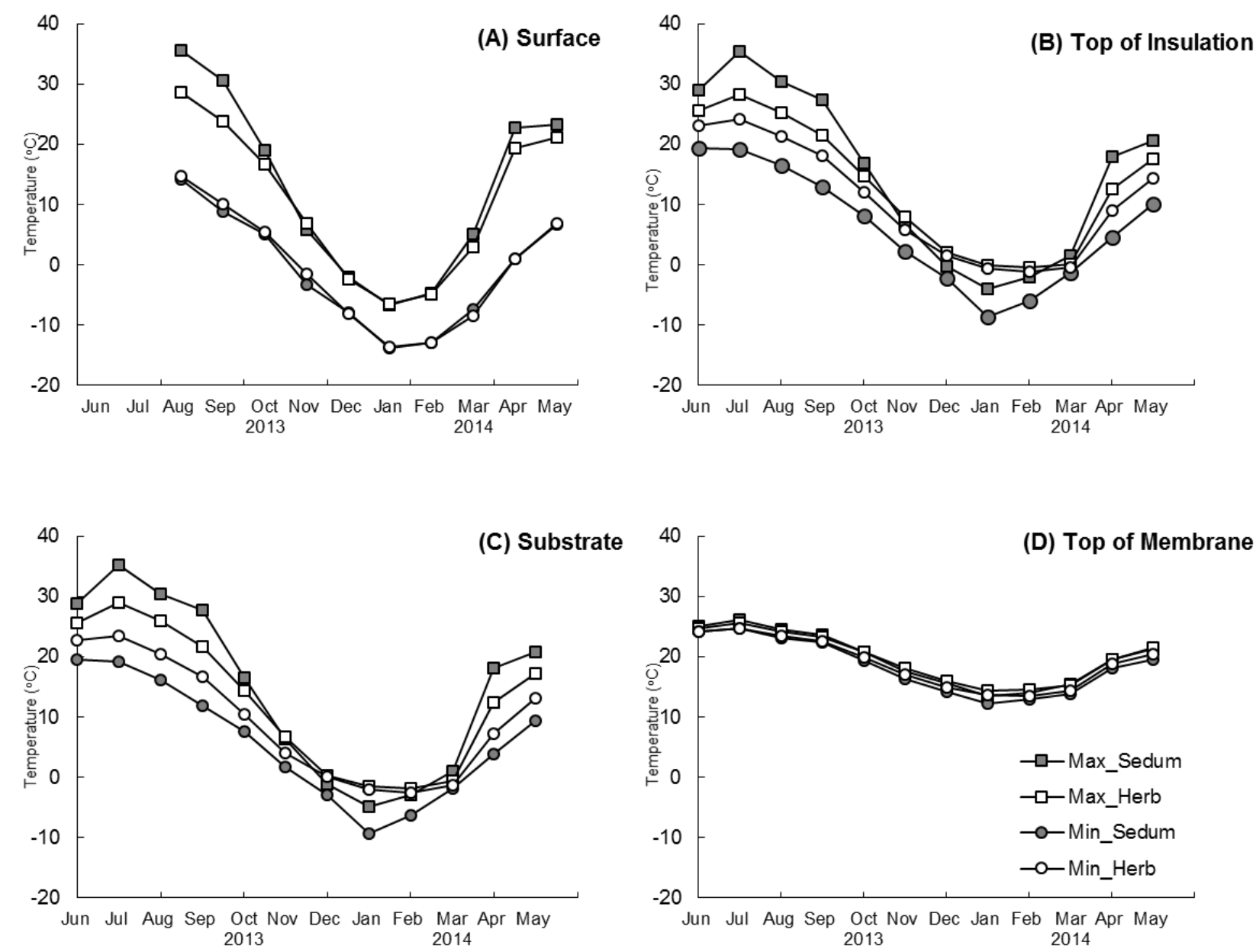

Fig. 9. Daily maximum and minimum temperatures values averaged for each month over the course of a year for (A) surface, (B) top of roof insulation, ( C) substrate, (D) Top of roofing membrane for Sedum and herbaceous portion of the green roof. in heat loss or heat gain than on the herbaceous portion. During drought periods, heat flux was 
generally inward (negative), whereas, when precipitation was present, heat flux was outward (positive). Factors likely influencing measurements included plant species or plant type, percentage of plant cover that provided shade, substrate depth acting as an insulator, substrate moisture content, evapotranspiration, and weather conditions such as ambient air temperature and solar radiation. Thermal resistance (units $\mathrm{L}^{2} \mathrm{~T} /(\mathrm{E} / \mathrm{t})$ ) is defined from the global and ideally steady-state formula $K=\Delta T / Q$, where $\Delta T$ is the temperature difference across the material and $Q$ is the net heat flux across the material which in this case is the green roof substrate along with the insulation and membrane layers. In transient situations the temperature difference $\Delta T$ can lag the heat flux $Q$ in everyday cases where, for example, the heat flux changes sign from negative (in) to positive (out) through zero. In such cases transient spikes are observed in $\mathrm{K}$ [3] which must be filtered to produce a reliable $\mathrm{K}$-value. This behavior indicates that $\mathrm{K}$ is a steady-state quantity whose measurement at certain times of the day will be problematic. A scientifically more accurate definition of the heat flux is through the Fourier conduction law, $q^{\prime \prime}=-k \partial T / \partial x$, where coordinate $x$ aligns with the heat-flow direction and $k$ is the pointwise or local thermal conductivity. The latter is very difficult to measure for composite materials such as soils supporting branched in-depth root structures in addition to varying levels of moisture. This appears to be a discipline warranting serious study.

Regarding plant species, in an experiment where different green roofs were planted with either shrubs, trees, turf, or bare substrate, the total amount of heat gained was 0, 15.6, 29.2, and 86.6 $\mathrm{kJ} / \mathrm{m} 2$, respectively [30]. These values compared to $366.3 \mathrm{~kJ} / \mathrm{m} 2$ for the conventional roof without plants. Wong et al. [37] also found that energy consumption was less for tree and shrubs relative to turfgrass and Blanusa et al. [29] reported that the broadleaf Stachys byzantina experienced lower leaf surface temperatures and a higher transpiration than a sedum mix under both moist and dry conditions. In contrast, Zhao et al. [38] reported that there were no differences in heat flux among plant species or substrates although the building they studied was well insulated. Morphological and physiological differences in plants include albedo (reflection coefficient), height and width, LAI, form of metabolism (C3, C4, or CAM), and stomatal resistance which influences transpiration [11, 39-41]. Takakura et al. [42] reported that $30 \%$ of the cooling on a green roof was due to transpiration. Even though our study shows that plant type does make a difference, other studies suggest that the percentage of plant cover may be a more important factor influencing thermal properties than plant species. Shade decreases substrate surface temperatures by decreasing the solar radiation that 
reaches the substrate surface [28]. Coverage also influences leaf area index and albedo, a reflection coefficient that describes the amount of solar radiation reflected by the surface [11].

Franzaring et al. [25] reported that the succulent Phedimus floriferus (synonymous to Sedum kamtschaticum var. floriferum), performed better at cooling the roof on individual days and over the long term than the grass Koeleria glauca, the legume Lotus corniculatus, the herb Dianthus carthusianorum and the evergreen mini-shrub Thymus serpyllum). Phedimus floriferus exhibits a much lower rate of transpiration, but the authors attributed its superiority to its low, spreading growth habit which shaded a higher percentage of the substrate relative to the more upright species. Also, the drought tolerant nature of $P$. floriferus allowed it to survive and remain green for the duration of the experiment, thus providing a longer cooling window [25]. Similarly, Maclvor et al. [26] made the same conclusion, suggesting that sedum should be promoted to improve green roof cooling due to its consistent, near $100 \%$ vegetative cover. Results of additional studies also support this assumption [15, $27,37]$. In the present study, both the sedum and herbaceous portions of the roof were near $100 \%$ coverage so plant cover should not have been a factor.

Tied to plant species is substrate depth. Many studies have shown that deeper substrates are better at reducing the heat gain/loss through the roof [2, 27, 37]. Wong et al. [13] reported that for every $10 \mathrm{~cm}$ increase in substrate depth, thermal resistance of a dry clay soil increased by $0.4 \mathrm{~m}^{2}$ K/W. Sailor et al. [11] addressed the importance of depth by claiming that substrate depth was a larger factor than vegetation. Solar energy heats a shallow substrate layer more quickly resulting in higher ET and faster water depletion [14]. In contrast, one study showed that doubling substrate depth from $7.5 \mathrm{~cm}$ to $15 \mathrm{~cm}$ had no effect on reducing net heat loss [15]. Shallow depths dry quicker, but in some cases with greater depths, more water is distributed near the bottom, thus limiting ET [43].

In our study, throughout the year, moisture content of the deeper herbaceous portion of the green roof ranged from 0.04 to 0.20 , whereas moisture content of the sedum portion varied from 0.04 to 0.15 . The herbaceous substrate was generally higher because of the greater water retention capability of the deeper substrate and the larger canopy of the herbaceous plants helped shade the surface.

Several studies have shown that moisture increases the thermal conductivity of the substrate $[16,17,21,38,44]$. Sailor and Hagos [16] showed that thermal conductivity nearly tripled as substrate moisture increased from dry to saturated. In contrast, Tabares-Velasco and Srebric [24] reported that 
the lowest summer heat flux occurred on a wet roof, despite the higher substrate thermal conductivity, possibly because the radiant influx went to moisture evaporation rather than heating. Differences in results could be due to weather conditions as higher substrate moisture can cool the substrate on sunny days, but warm it on rainy and cloudy days [14]. Generally, it is thought that heat will be drawn out of a building when ET rates are high. For example, a wet green roof lost twice as much heat via ET during the summer than a dry green roof [21].

Evapotranspiration can be a huge factor for cooling. Sun et al. [43] found that irrigating a green roof in Beijing was a more cost effective cooling strategy than operating air conditioners. Mankiewicz et al. [44] arrived at the same conclusion in New York. They attributed this finding to increased ET and that there is a significant amount of water needed to produce the electricity needed to operate the air conditioners. However, Jim and Peng [14] found that substrate moisture was effective in regulating substrate temperature, but had a limited influence on ET and the associated cooling which is largely dependent on solar radiation, relative humidity, and wind speed.

Although, our sedum roof exhibited more extremes, when daily heat flux values were totaled for each month and each season, the herbaceous roof actually experienced more heat entering the building (or less heat leaving the building) (Table 2). This is an advantage during the winter months as the herbaceous roof would save on heating bills. However, contrary to conventional logic that plants with high transpiration rates are superior, during the summer months the sedum roof outperformed the herbaceous roof. During summer, a sum of positive and negative heat flux values at the membrane showed that the herbaceous roof transferred $432 \mathrm{~W} \cdot \mathrm{m}^{-2}$ of heat into the building, whereas the sedum roof lost $1136 \mathrm{~W} \cdot \mathrm{m}^{-2}$ of heat out of the building.

This was due in part to the quick saturation of the shallower substrate during a rain event and subsequent rapid drying by ET. Also, the larger volume of substrate on the herbaceous roof acted as a heat sink and continued to transfer heat into the building during the evening and early morning hours. Jim [45] reported similar results in sub-tropical Hong Kong where summer energy consumption (energy transferred into the building) was higher for a roof covered with the herbaceous perennial, Arachis pintoi, relative to a roof planted with the succulent, Sedum mexicanum. Likewise, Franzaring et al. [25] reported that as substrates warmed during the day, they often retained this heat to the point where night time substrate temperatures were often higher than ambient air temperatures. The deeper substrate layers for the herbaceous perennials were capable of holding more moisture and the higher 
thermal capacity of the wet substrates slowed temperature drop which led to more heat being transferred, by conduction, into the building during the night [19].

As stated by Jim and He [46] temporal heat-flux fluctuations are strongly correlated with meteorological variables and temperature is one of the key determinants of heat flux. During our study differences between heat fluxes on the two green roofs were greatest during summer due to environmental conditions. Different seasonal ambient temperatures and solar radiation levels

\section{4 influenced the heat flux.}

Table 2. Monthly and seasonal cumulative heat flux $\left(\mathrm{W} \cdot \mathrm{m}^{-2}\right)$ of the different green roof types.

\begin{tabular}{|c|c|c|c|c|c|c|c|c|c|c|c|}
\hline \multirow{3}{*}{ Season } & \multirow{3}{*}{ Month } & \multicolumn{4}{|c|}{ Cumulative Heat flux $\left(\mathrm{W} \cdot \mathrm{m}^{-2}\right)$} & \multicolumn{4}{|c|}{$\begin{array}{l}\text { Monthly cumulative heat flux } \\
\text { averaged over a season }\left(\mathrm{W} \cdot \mathrm{m}^{-2}\right)\end{array}$} & \multirow{2}{*}{\multicolumn{2}{|c|}{$\begin{array}{l}\text { Change }(\%) \text { in heat flux } \\
\text { comparing herbaceous to } \\
\text { sedum roof }\end{array}$}} \\
\hline & & \multicolumn{2}{|c|}{ Membrane } & \multicolumn{2}{|c|}{ Insulation } & \multicolumn{2}{|c|}{ Membrane } & \multicolumn{2}{|c|}{ Insulation } & & \\
\hline & & Sedum & Herb. & Sedum & Herb. & Sedum & Herb. & Sedum & Herb. & Membrane & Insulation \\
\hline \multirow{3}{*}{ Summer } & June & 178 & -52 & 83 & 31 & \multirow{3}{*}{379} & \multirow{3}{*}{-144} & \multirow{3}{*}{-93} & \multirow{3}{*}{-102} & \multirow{3}{*}{137.9} & \multirow{3}{*}{9.7} \\
\hline & July & 315 & -510 & -402 & -361 & & & & & & \\
\hline & August & 643 & 130 & 39 & 22 & & & & & & \\
\hline \multirow{3}{*}{ Autumn } & September & 1413 & 990 & 1005 & 1181 & \multirow{3}{*}{2758} & \multirow{3}{*}{2232} & \multirow{3}{*}{2826} & \multirow{3}{*}{2535} & \multirow{3}{*}{19.1} & \multirow{3}{*}{10.3} \\
\hline & October & 3076 & 2605 & 3126 & 2823 & & & & & & \\
\hline & November & 3786 & 3102 & 4346 & 3599 & & & & & & \\
\hline \multirow{3}{*}{ Winter } & December & 5767 & 4613 & 7056 & 5729 & \multirow{3}{*}{5485} & \multirow{3}{*}{3303} & \multirow{3}{*}{7464} & \multirow{3}{*}{5271} & \multirow{3}{*}{39.8} & \multirow{3}{*}{29.4} \\
\hline & January & 5054 & 1993 & 6897 & 4240 & & & & & & \\
\hline & February & 5635 & - & 8438 & 5845 & & & & & & \\
\hline \multirow{3}{*}{ Spring } & Mar & 5561 & - & 6334 & 6318 & \multirow{3}{*}{3432} & \multirow{3}{*}{ - } & \multirow{3}{*}{4683} & & & \\
\hline & April & 3083 & - & 3032 & 2657 & & & & 4487 & - & 4.2 \\
\hline & May & 1651 & - & 1291 & - & & & & & & \\
\hline Sedum $=$ & f portion & ered with & edum & rown ma & & & & & & & \\
\hline$=$ & ortion $p$ & with & rbaceous & nnial & gras & & & & & & \\
\hline Membra & $=$ Roofing & mbrane & ter roof & ions. & & & & & & & \\
\hline
\end{tabular}

\section{Conclusions}

Results demonstrate the influence of vegetation type and depth on heat flux and temperature distribution over the course of a year in Michigan. Thermal protection provided by herbaceous plants was greater due to its deeper growing substrate and shade provided by the plant canopy. Maximum and minimum temperatures, fluctuations in temperature, and heat flux tended to be more stable under 
the herbaceous roof. It is difficult to determine whether plant species or substrate depth is the more important factor. Although, the sedum roof exhibited greater extremes, the herbaceous roof actually experienced more heat entering the building (or less heat leaving the building). This is an advantage during the winter months as the herbaceous roof would save on heating bills, but not in the summer when a greater amount of air conditioning would be required. However, contrary to conventional logic that plants with high transpiration rates are superior, during the summer months the sedum roof outperformed the herbaceous roof.

As stated, the conclusions drawn from this study applies to Michigan and locations with a similar climate. But how would these results translate to other climates? In a warmer climate such as the southern United States, night-time radiation of heat into the building from a deep substrate layer would likely be more severe because sun exposure and warmer air temperatures would heat the substrate to a higher temperature. In contrast, in a cooler summer climate such as that experienced on the east coast of Canada, this night-time heat gain may not even occur. Likewise, Michigan normally experiences snow cover throughout winter which acts as an extra insulation layer on the roof. Thus, snow diminishes the amount of heat that could escape the building through a shallow extensive green roof. Lake-effect snow is common, a phenomenon that would not occur in areas where large bodies of water did not exist. In locations that experience cold temperatures with limited snowfall, the loss of heat through a shallow extensive roof would be more pronounced than it is in Michigan. Regardless of roof location or depth and plant species used, installing a green roof vastly improves energy efficiency relative to a standard roof without vegetation.

\section{Acknowledgements}

This project was supported by the USDA National Institute of Food and Agriculture, the Michigan Department of Agriculture and Natural Resources, and by AgBioResearch at Michigan State University. Additional funding was provided by TUBITAK (The Scientific and Technical Research Council of Turkey) 2219 International Postdoctoral Research Scholarship Programme; XeroFlor America, Durham, NC; and Wildtype Nursery, Mason, MI. Mert Eksi was a visiting scholar at MSU during 2013-14. The authors acknowledge technical assistance from Kristin L. Getter, Rafael Fernández Cañero, and Jason Ritter. 
[1] H.F. Castleton, V. Stovin, S.B.M. Beck, J.B. Davison, Green roofs: building energy savings and the potential for retrofit, Energy and Buildings 42 (2010) 1582-1591.

[2] O. Saadatian, K. Sopian, E. Salleh, C.H. Lim, S. Riffat, E. Saadatian, A. Toudeshki, M.Y. Sulaiman, A review of energy aspects of green roofs, Renewable and Sustainable Energy Reviews 23 (2013) 155-168.

[3] K.L. Getter, D. B. Rowe, J.A. Andresen, I.S. Wichman, Seasonal heat flux properties of an extensive green roof in a Midwestern U.S. climate, Energy and Buildings 43 (2011) 3548-3557. (http://dx.doi.org/10.1016/i.enbuild.2011.09.018).

[4] USEPA. Vegetated roof cover. Report EPA 841-B-00-005D. Washington, DC: U.S. Environmental Protection Agency, 2000.

[5] K.L. Getter, D.B. Rowe, G.P. Robertson, B.M. Cregg, J.A. Andresen, Carbon sequestration potential of extensive green roofs, Environ. Sci. Technol. 43 (2009) 7564-7570.

(http://dx.doi.org/10.1021/es901539x).

[6] E. Oberndorfer, J. Lundholm, B. Bass, R.R. Coffman, H. Doshi, N. Dunnett, S. Gaffin, M. Ko"hler, K.K.Y. Liu, D.B. Rowe, Green roofs as urban ecosystems: ecological structures, functions, and services, BioScience 57 (2007) 823-833.

[7] D.B. Rowe, Green roofs as a means of pollution abatement, Environmental Pollution. 159 (8-9) (2011) 2100-2110. (http://dx.doi.org/10.1016/j.envpol.2010.10.029).

[8] L.J. Whittinghill, D.B. Rowe. The role of green roof technology in urban agriculture. Renewable Agriculture and Food Systems 27(4) (2012) 314-322.

(http://dx.doi.org/10.1017/S174217051100038X).

[9] S. Ouldboukhitine, R. Belarbi, R. Djedjig, Characterization of green roof components: measurements of thermal and hydrological properties, Building and Environment 56 (2012) 78-85.

[10] P.C. Tabares-Velasco, J. Srebric, Experimental quantification of heat and mass transfer process through vegetated roof samples in a new laboratory setup, International Journal of Heat and Mass Transfer 54 (2011) 5149-5162.

[11] D.J. Sailor, A green roof model for building energy simulation programs, Energy and Buildings 40 (2008) 1466-1478.

[12] T.G. Theodosiou, Summer period analysis of the performance of a planted roof as a passive cooling technique, Energy and Buildings 35 (2003) 909-917.

[13] N.H. Wong, D.K.W. Cheong, H. Yan, J. Soh, C.L. Ong, A. Sia, The effects of rooftop garden on energy consumption of a commercial building in Singapore, Energy and Buildings 35 (2003b) 353-364.

[14] C.Y Jim, L.L.H. Peng, Substrate moisture effect on water balance and thermal regime of a tropical extensive green roof, Ecological Engineering 47 (2012b) 9-23.

(http://dx.doi.org/10.1016/j.ecoleng.2012.06.020).

[15] J.T. Lundholm, B.M. Weddle, J. S. Maclvor, Snow depth and vegetation type affect green roof thermal performance in winter. Energy and Buildings 84 (2014) 299-307. (doi.org/doi:10.1016/i.enbuild.2014.07.093).

[16] D.J. Sailor, M. Hagos. An updated and expanded set of thermal property data for green roof growing media. Energy and Buildings 43 (2011) 2298-2303.

(http://dx.doi.org/10.1016/j.enbuild.2011.05.014). 
[17] A. Pianella, R.E. Clarke, N.S.G. Williams, Z. Chen, L. Aye, Steady-state and transient thermal measurements of green roof substrates, Energy and Buildings (In press)(2016). (http://dx.doi.org/10.1016/j.enbuild.2016.09.024).

[18] R. Fioretti, A. Palla, L.G. Lanza, P. Principi, Green roof energy and water related performance in the Mediterranean climate. Building and Environment 45(8) (2010) 1890-1904.

[19] C.Y. Jim, L.L. Peng, Weather effect on thermal and energy performance of an extensive tropical green roof. Urban Forestry \& Urban Greening 11(1) (2012a) 73-85.

[20] R. Kumar, S.C. Kaushik, Performance evaluation of green roof and shading for thermal protection of buildings, Building and Environment 40 (2005) 1505-1511.

[21] R.M. Lazzarin, F. Castellotti, F. Busato, Experimental measurements and numerical modelling of a green roof, Energy and Buildings 37(12) (2005) 1260-1267.

[22] M. Santamouris, C. Pavlou, P. Doukas, G. Mihalakakou, A. Synnefa, A. Hatzibiros, P. Patargias, Investigating and analysing the energy and environmental performance of an experimental green roof system installed in a nursery school building in Athens, Greece, Energy, 32(9) (2007) 1781-1788.

[23] T. Susca, S.R. Gaffin, G.R. Dell'Osso, Positive effects of vegetation: urban heat island and green roofs. Environmental Pollution 159(8) (2011) 2119-2126.

[24] P.C. Tabares-Velasco, J. Srebric, The role of plants in the reduction of heat flux through green roofs: laboratory experiments, ASHRAE Transactions 115 (2009) 793-802.

[25] L. Franzaring, J., Steffan, W. Ansel, R. Walker, A. Fangmeier, Water retention, wash-out, substrate and surface temperatures of extensive green roof mesocosms - results from a two year study in SW-Germany, Ecological Engineering 94 (2016) 503-515.

(http://dx.doi.org/10.1016/j.ecoleng.2016.06.021).

[26] J.S. Maclvor, L. Margolis, M. Perotto, J.A.P. Drake, Air temperature cooling by extensive green roofs in Toronto Canada, Ecological Engineering 95 (2016) 36-42.

(http://dx.doi.org/10.1016/j.ecoleng.2016.06.050).

[27] M. Buckland-Nicks, A. Heim, J. Lundholm, Spatial environmental heterogeneity affects plant growth and thermal performance on a green roof, Science of the Total Environment 553 (2016) 20-31. (http://dx.doi.org/10.1016/..scitotenv.2016.02.063).

[28] N. Yaghoobian, J. Srebric. Influence of plant coverage on the total green roof energy balance and building energy consumption, Energy and Buildings 103 (2015) 1-13. (http://dx.doi.org/10.1016/i.enbuild.2015.05.052).

[29] T. Blanusa, M.M.V. Monteiro, F. Fantozzi, E. Vysini, Y. Li, R.W. Cameron, Alternatives to Sedum on green roofs: Can broad leaf perennial plants offer better 'cooling service'?, Building and Environment 59 (2013) 99-106. (http://dx.doi.org/10.1016/..buildenv.2012.08.011).

[30] D.E. Bowler, L. Buyung-Ali, T.M. Knight, A.S. Pullin, Urban greening to cool towns and cities: a systematic review of the empirical evidence, Landscape and Urban Planning 97 (2010) 147-55.

(31) U.S. Climate Data. 2017. www.usclimatedata.com/climate/lansing/michigan/unitedstates/usmi0477. Accessed February 2, 2017.

[32] M. Bittelli, F. Ventura, G.S. Campbell, R.L. Snyder, F. Gallegati, P.R. Pisa, Coupling of heat, water vapor, and liquid water fluxes to compute evaporation in bare soils, Journal of Hydrology 362(3) (2008) 191-205.

[33] P. Castiglione, P.J. Shouse, The effect of ohmic cable losses on time-domain reflectometry measurements of electrical conductivity, Soil Sci Soc Am J. 67 (2003) 414-424. 
[34] F.F. Da Silva, R. Wallach, A. Polak, Y. Chen, Measuring water content of soil substitutes with time-domain reflectometry (TDR). Journal of the American Society for Horticultural Science 123(4)

[35] M. Squier, C. Davidson, Heat flux and seasonal thermal performance of an extensive green roof, Building and Environment (In press) (2016) (http://dx.doi.org/10.1016/j.buildenv.2016.07.025).

[36] M. Zhao, J. Srebric, R.D. Berghage, K.A. Dressler, Accumulated snow layer Influence on the heat transfer process through green roof assemblies, Building and Environment 87 (2015) 82-91. (http://dx.doi.org/10.1016/i.buildenv.2014.12.018).

[37] N.H. Wong, Y. Chen, C.L. Ong, A. Sia, Investigation of thermal benefits of rooftop garden in the tropical environment, Building and Environment 38 (2003a) 261-270.

[38] M. Zhao, P.C. Tabares-Velasco, J. Srebric, S. Komarneni, R. Berghage, Effects of plant and substrate selection on thermal performance of green roofs during the summer, Building and Environment 78 (2014) 199-211. (http://dx.doi.org/10.1016/i.buildenv.2014.02.011)

[39] S. Hodo-Abalo, M. Banna, B. Zeghmati, Performance analysis of a planted roof as a passive cooling technique in hot-humid tropics, Renewable Energy 39 (2012) 140-148.

[40] I. Jaffal, S. Ouldboukhitine, R. Belarbi, A comprehensive study of the impact of green roofs on building energy performance, Renewable Energy 43 (2012) 157-64.

[41] K.S. Lee, J. Kim, Changes in Crassulacean acid metabolism (CAM) of Sedum plants with special reference to soil moisture conditions, J. Plant Biology 37(1) (1994) 9-15.

[42] T. Takakura, S. Kitade, E. Goto, Cooling effect of greenery cover over a building, Energy and Buildings 31 (2000) 1-6.

[43] T. Sun, E. Bou-Zeid, G. Ni, To irrigate or not to irrigate: analysis of green roof performance via a vertically-resolved hygrothermal model, Building and Environment 73 (2014) 127-137. (http://dx.doi.org/10.1016/j.buildenv.2013.12.004).

[44] P. Mankiewicz, P. Spartos, E. Dalski, Green roofs and local temperature: how green roofs partition water, energy, and costs in urban energy-air conditioning budgets. In: Proceedings of 7th North American Green Roof Conference: Greening Rooftops for Sustainable Communities, Atlanta, GA (2009).

[45] C.Y. Jim, Heat-sink effect and indoor warming imposed by tropical extensive green roof. Ecological Engineering 62 (2014) 1-12. (http://dx.doi.org/10.1016/j.ecoleng.2013.10.022).

[46] C.Y. Jim, H. He, Coupling heat flux dynamics with meteorological conditions in the green roof ecosystem, Ecological Engineering 36 (2010) 1052-1063. 